\title{
Four new Ophiostoma species associated with conifer- and hardwood-infesting bark and ambrosia beetles from the Czech Republic and Poland
}

\author{
Robert Jankowiak (i) P Piotr Bilański • Beata Strzałka • Riikka Linnakoski • \\ Agnieszka Bosak · Georg Hausner
}

Received: 30 November 2018/ Accepted: 14 May 2019/Published online: 28 May 2019

(C) The Author(s) 2019

\begin{abstract}
Fungi under the order Ophiostomatales (Ascomycota) are known to associate with various species of bark beetles (Coleoptera: Curculionidae: Scolytinae). In addition this group of fungi contains many taxa that can impart blue-stain on sapwood and some are important tree pathogens. A recent survey that focussed on the diversity of the Ophiostomatales in the forest ecosystems of the Czech Republic and Poland uncovered four putative new species. Phylogenetic analyses of four gene regions (ITS1-5.8S-ITS2 region, $\beta$-tubulin, calmodulin, and translation elongation factor 1- $\alpha$ ) indicated that these four species are members of the genus Ophiostoma. All four newly described species can be distinguished from each other and from closely related species based on DNA sequence comparisons, morphological characters,
\end{abstract}

Electronic supplementary material The online version of this article (https://doi.org/10.1007/s10482-019-01277-5) contains supplementary material, which is available to authorized users.

R. Jankowiak $(\bowtie) \cdot$ B. Strzałka $\cdot$ A. Bosak

Department of Forest Pathology, Mycology and Tree

Physiology, Institute of Forest Ecosystem Protection,

University of Agriculture in Krakow, Al. 29 Listopada 46,

31-425 Kraków, Poland

e-mail: rljankow@cyf-kr.edu.pl

P. Bilański

Department of Forest Protection, Entomology and Forest Climatology, Institute of Forest Ecosystem Protection,

University of Agriculture in Krakow, Al. 29 Listopada 46,

31-425 Kraków, Poland growth rates, and their insect associations. Based on this study four new taxa can be circumscribed and the following names are provided: Ophiostoma pityokteinis sp. nov., Ophiostoma rufum sp. nov., Ophiostoma solheimii sp. nov., and Ophiostoma taphrorychi sp. nov. $O$. rufum sp. nov. is a member of the Ophiostoma piceae species complex, while $O$. pityokteinis sp. nov. resides in a discrete lineage within Ophiostoma s. stricto. O. taphrorychi sp. nov. together with $O$. distortum formed a well-supported clade in Ophiostoma s. stricto close to O. pityokteinis sp. nov. $O$. solheimii sp. nov. groups within a currently undefined lineage A, which also includes Ophiostoma grandicarpum and Ophiostoma microsporum. This study highlights the need for more intensive surveys that should include additional countries of Central Europe, insect vectors and host tree species in order to elucidate Ophiostoma species diversity in this region.

\author{
R. Linnakoski \\ Natural Resources Institute Finland (Luke), \\ Latokartanonkaari 9, 00790 Helsinki, Finland \\ G. Hausner \\ Department of Microbiology, Buller Building 213, \\ University of Manitoba, Winnipeg R3T 2N2, Canada
}


Keywords Conifers - Hardwoods - 4 New taxa · Ophiostoma piceae species complex

\section{Introduction}

The order Ophiostomatales includes seven well supported lineages represented by the following genera: Aureovirgo, Ceratocystiopsis, Fragosphaeria, Graphilbum, Hawksworthiomyces, Raffaelea s. stricto, and Sporothrix. Two additional major groups, for which monophyly is not well supported, are Leptographium s. lato and Ophiostoma s. lato (De Beer and Wingfield 2013; De Beer et al. 2016). The Ophiostomatales also contain some smaller lineages with uncertain taxonomic positions, such as lineages A, B, C and D (De Beer et al. 2016).

Species of Ophiostoma Syd. \& P. Syd. (Sydow and Sydow 1919) reside in Ophiostoma s. stricto (Ophiostomatales, Ascomycota) (De Beer et al. 2016). Currently, Ophiostoma s. stricto includes six species complexes: O. ulmi, O. pluriannulatum, O. ips, $O$. clavatum, O. minus, and $O$. piceae species complexes (De Beer and Wingfield 2013; Linnakoski et al. 2016; Yin et al. 2016; Chang et al. 2019). The genus Ophiostoma currently includes nearly 40 described taxa, most of which are associated with phloem and wood-dwelling beetles. The most important morphological features that can be used to describe these fungi are ascomata with short to long necks, crescent to allantoid shaped ascospores, and pesotum-, hyalorhinocladiella- or sporothrix-like asexual morphs (De Beer and Wingfield 2013). Most Ophiostoma species produce spores in sticky droplets that can easily attach to the exoskeletons of their insect vectors (Malloch and Blackwell 1993). The genus Ophiostoma includes plant-associated species with varying degrees of pathogenicity. Most members are considered as nonpathogenic, especially in their endemic range, where they have co-evolved with their host tree species, and are mainly responsible for causing blue-stain in freshly exposed sapwood (Wingfield et al. 2017). However, some Ophiostoma species are highly virulent tree pathogens that have been responsible for tree death in natural as well as managed forest ecosystems (Harrington 1993). In many cases, pathogenicity and tree damage caused by these fungi are linked to their introduction into new areas (Loo 2009; Wingfield et al. 2015).

Members of the Ophiostomatales, that exist in symbiosis with bark beetles in Central Europe, have been mainly described from Austria (e.g. Kirisits 2001), Germany (e.g. Kirschner 2001), Poland (e.g. Siemaszko 1939; Jankowiak 2005, 2006, 2008; Jankowiak and Bilański 2013) and from a limited number of reports from the Czech Republic and Slovakia (e.g. Kotýnková-Sychrová 1966). These studies reported numerous species belonging to the Ophiostomatales that were in association with conifer- and hardwoodinfesting bark beetles. However, the diversity of ophiostomatoid fungi associated with Abies alba, Larix decidua and hardwood trees are not well studied. For this reason, several comprehensive studies have been undertaken in recent years to explore the diversity of ophiostomatoid fungi in Central Europe (Jankowiak et al. 2017a, 2019). As part of a fungal diversity survey conducted in the Czech Republic and Poland (Jankowiak et al. 2017a, 2019) a total of 30 undescribed Ophiostomatales taxa associated with hardwood- and conifer-infesting beetles were uncovered. Until now, only six of these have been formally described as new species (Jankowiak et al. 2017b, 2018; Aas et al. 2018).

In this study, both morphological characters and DNA sequence data from the ITS region (ITS1-5.8SITS2), and three protein coding genes ( $\beta$-tubulin, calmodulin, translation elongation factor $1-\alpha$ ) were analysed to a) characterise the four new species within Ophiostoma s. lato, and compare them to closely related known species within the Ophiostomatales, and b) to provide a formal description for these new species.

\section{Materials and methods}

Isolates and herbarium specimens

Bark beetles and galleries were collected during a study conducted by Jankowiak et al. (2017a, 2019). Fungal isolations were made from beetles collected in Poland, and this included the following beetle species: Pityokteines vorontzowi, Pityokteines curvidens, Anisandrus dispar, Taphrorychus bicolor and Scolytus intricatus (Fig. 1). In addition, materials investigated in this study included fungi that were isolated from Ips 


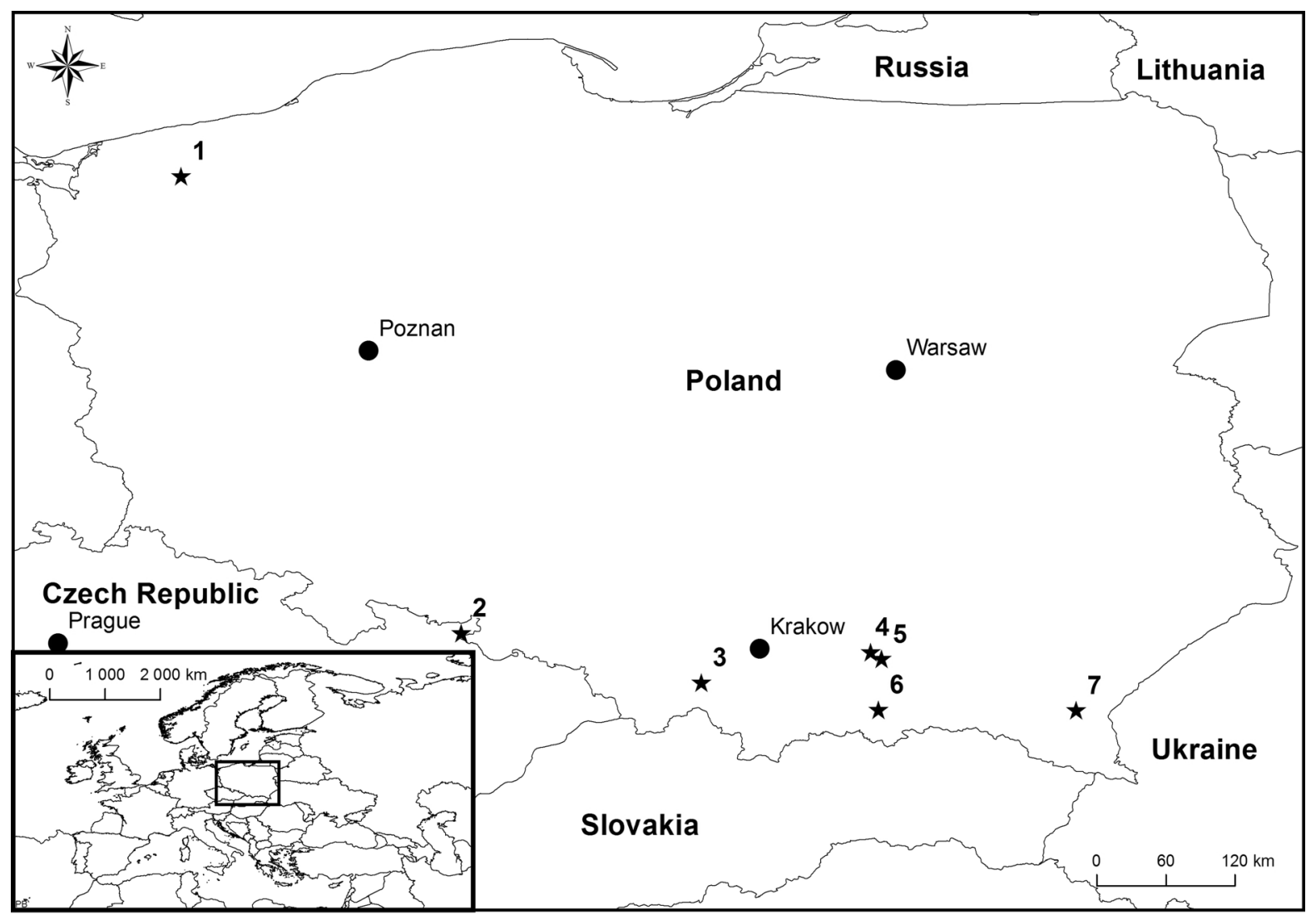

Fig. 1 Geographic origins of isolates used in this study: 1Resko, Poland $\left(53^{\circ} 45^{\prime} 56.18^{\prime \prime} \mathrm{N}, 1^{\circ} 25^{\prime} 19.25^{\prime \prime} \mathrm{E}\right)$; 2-Albrechtice, Czech Republic $\left(50^{\circ} 11^{\prime} 18.00^{\prime \prime} \mathrm{N}, 17^{\circ} 36^{\prime} 39.90^{\prime \prime} \mathrm{E}\right)$; 3 -Mucharz, Poland $\left(49^{\circ} 48^{\prime} 7.98^{\prime \prime} \mathrm{N}, 1^{\circ} 29^{\prime} 19.50^{\prime \prime} \mathrm{E}\right) ; 4$ Wierzchosławice, Poland $\left(50^{\circ} 2^{\prime} 21.06^{\prime \prime} \mathrm{N}, 20^{\circ} 48^{\prime} 49.32^{\prime \prime} \mathrm{E}\right) ; 5-$

cembrae in the Czech Republic (Table 1). Fungal isolation strategy and the origin of some of the isolates used in this study have been described previously (Jankowiak et al. 2017a, 2019).

All fungal isolates used in this study are listed in Table 1. The isolates are maintained in the culture collection of the Department of Forest Pathology, Mycology and Tree Physiology; University of Agriculture in Krakow, Poland. The ex-type isolates of the new species described in this study were deposited in the Westerdijk Fungal Biodiversity Institute (CBS), Utrecht, the Netherlands, and in the culture collection (CMW) of the Forestry and Agricultural Biotechnology Institute (FABI), University of Pretoria, South Africa. Herbarium specimens have been deposited in the Herbarium of the University of Turku (TUR), Finland. Taxonomic descriptions and nomenclatural
Zbylitowska Góra, Poland $\left(49^{\circ} 59^{\prime} 9.28^{\prime \prime} \mathrm{N}, 20^{\circ} 53^{\prime} 55.27^{\prime \prime} \mathrm{E}\right)$;. 6 Nawojowa, Poland $\left(49^{\circ} 35^{\prime} 19.38^{\prime \prime} \mathrm{N}, \quad 20^{\circ} 52^{\prime} 28.49^{\prime \prime} \mathrm{E}\right)$; 7Rozpucie, Poland $\left(49^{\circ} 34^{\prime} 59.92^{\prime \prime} \mathrm{N}, 22^{\circ} 25^{\prime} 18.28^{\prime \prime} \mathrm{E}\right)$. Dark grey-forests, light grey—sea

data have been registered in MycoBank (www. MycoBank.org) (Robert et al. 2013).

DNA extraction, PCR and sequencing

The fungal isolates were grown on $2 \%$ malt extract agar [MEA: $20 \mathrm{~g} \mathrm{Bacto}^{\text {TM }}$ malt extract (BectonDickinson and Company, Franklin Lakes, USA), $20 \mathrm{~g}$ agar Bacto $^{\mathrm{TM}}$ agar powder from Becton-Dickinson and Company, Franklin Lakes, USA), 11 deionized water] in $90 \mathrm{~mm}$ plastic Petri dishes for 1-2 weeks prior to DNA extraction. DNA was extracted using the Genomic Mini AX Plant Kit (A\&A Biotechnology, Gdynia, Poland) according to the manufacturer's protocol.

Four loci, including ITS1-5.8 S-ITS2 (ITS), betatubulin $(\beta \mathrm{T})$, calmodulin (CAL) and translation 


\begin{tabular}{|c|c|c|c|c|c|c|c|c|c|c|c|c|c|c|c|c|c|}
\hline & 它 & 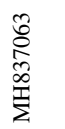 & 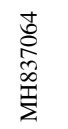 & 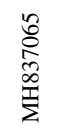 & 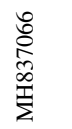 & 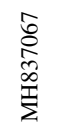 & 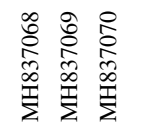 & 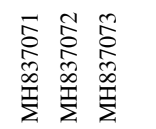 & 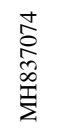 & 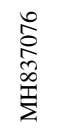 & I & 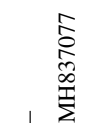 & $\begin{array}{l}\infty \\
\stackrel{\infty}{0} \\
\infty \\
\infty \\
\infty\end{array}$ & 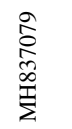 & 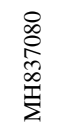 & 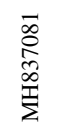 & 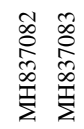 \\
\hline & 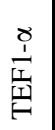 & 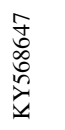 & 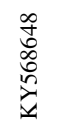 & 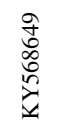 & 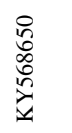 & 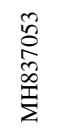 & 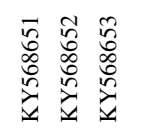 & 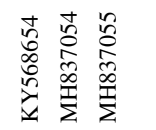 & 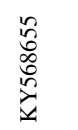 & 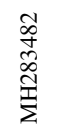 & 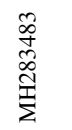 & 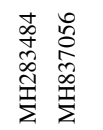 & 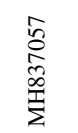 & 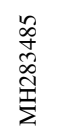 & $\begin{array}{l}\infty \\
0 \\
\infty \\
\infty \\
\infty \\
\infty_{\Sigma}^{\infty}\end{array}$ & 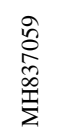 & 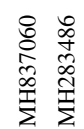 \\
\hline 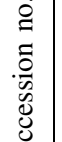 & 占 & 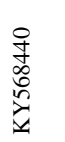 & 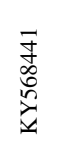 & 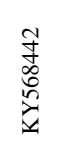 & 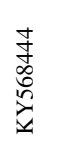 & 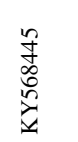 & 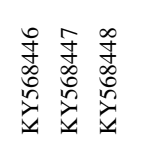 & 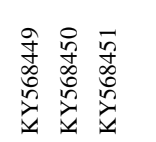 & 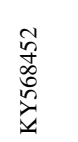 & 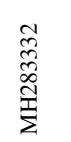 & 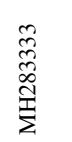 & 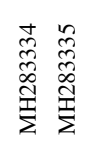 & 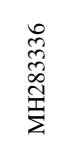 & $\begin{array}{l}\hat{\text { }} \\
\infty \\
\stackrel{1}{1} \\
\text { Ė }\end{array}$ & 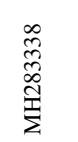 & 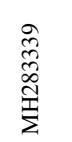 & 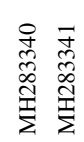 \\
\hline 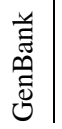 & $\triangleq$ & 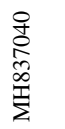 & 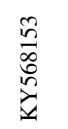 & 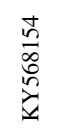 & 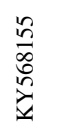 & 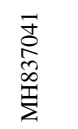 & 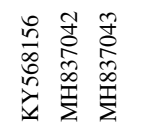 & 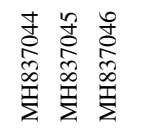 & 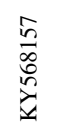 & & I & 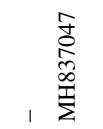 & $\begin{array}{l}\substack{\infty \\
⿱ 亠 乂 \\
\infty \\
\infty \\
\Sigma} \\
\sum\end{array}$ & 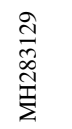 & $\begin{array}{l}\underset{d}{d} \\
\substack{\infty \\
\infty} \\
\sum^{\infty}\end{array}$ & 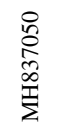 & 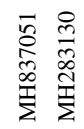 \\
\hline . & & 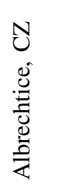 & 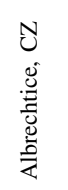 & 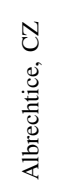 & 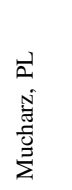 & 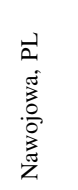 & 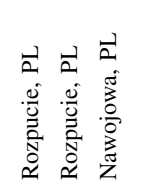 & 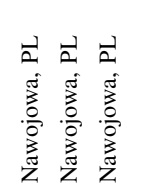 & 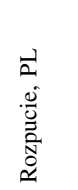 & 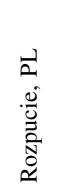 & 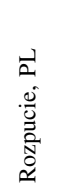 & 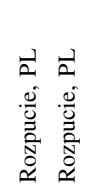 & 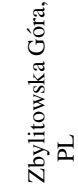 & 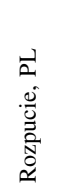 & 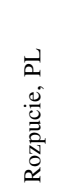 & 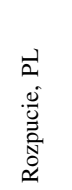 & 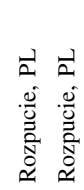 \\
\hline 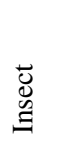 & & 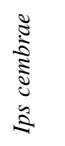 & 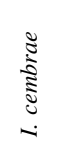 & 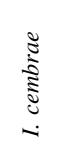 & 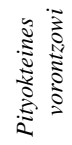 & 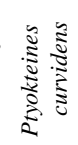 & 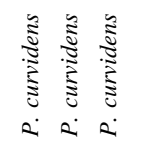 & 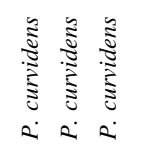 & 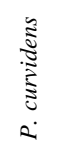 & 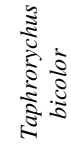 & 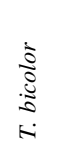 & 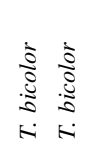 & 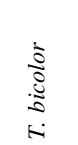 & 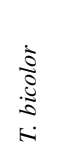 & 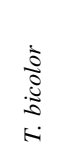 & 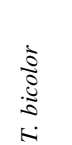 & 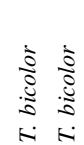 \\
\hline $\begin{array}{l}\overrightarrow{0} \\
\stackrel{\vec{I}}{1}\end{array}$ & & 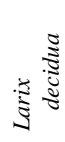 & 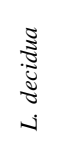 & 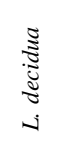 & 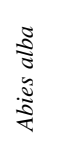 & $\begin{array}{l}\text { ปี } \\
\dot{+}\end{array}$ & 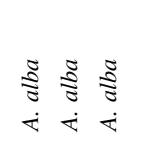 & 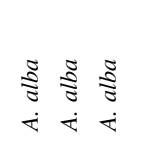 & 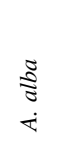 & 总 & 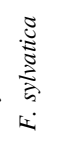 & 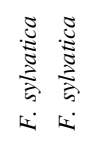 & 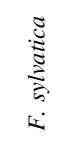 & 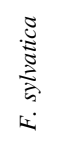 & 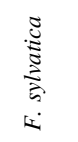 & 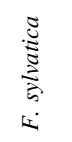 & 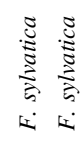 \\
\hline & $\frac{\bar{\Phi}}{\bar{\Xi}}$ & 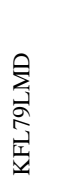 & 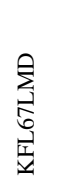 & 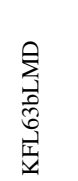 & 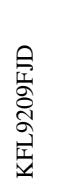 & 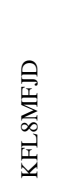 & 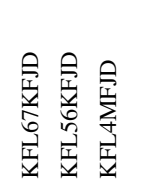 & 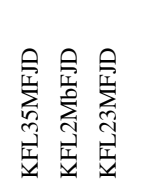 & 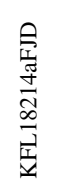 & 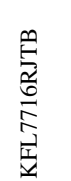 & 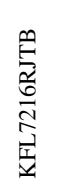 & 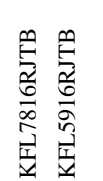 & 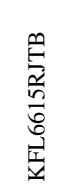 & 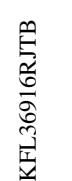 & 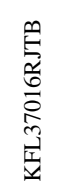 & 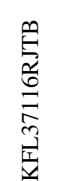 & 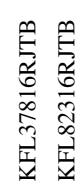 \\
\hline & 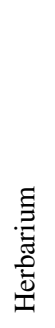 & 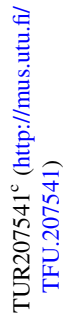 & 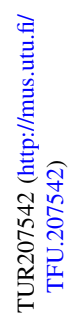 & 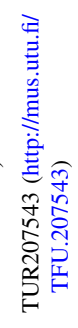 & 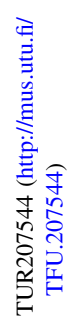 & & 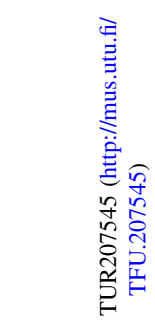 & 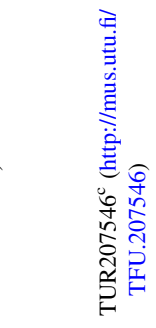 & 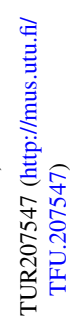 & & 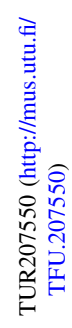 & 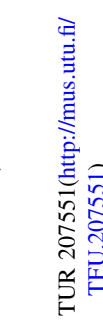 & & 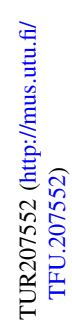 & 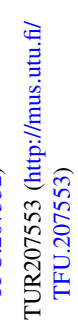 & 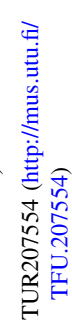 & \\
\hline$\stackrel{\square}{\circ}$ & ڤ̂ & 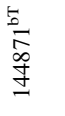 & 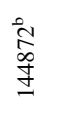 & 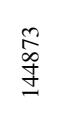 & $\underset{\substack{+\stackrel{\infty}{+}}}{\stackrel{+}{ \pm}}$ & 1 & 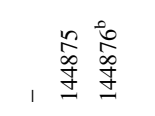 & 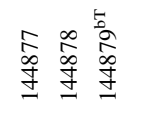 & $\begin{array}{l}\infty \\
\infty \\
\stackrel{\infty}{+} \\
\stackrel{+}{ \pm}\end{array}$ & & $\begin{array}{l}\underset{\infty}{\infty} \\
\stackrel{\infty}{ \pm} \\
\stackrel{J}{ \pm}\end{array}$ & 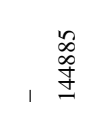 & $\begin{array}{l}\infty \\
\infty \\
\stackrel{o}{J} \\
\text { J }\end{array}$ & $\begin{array}{l}\bar{\infty} \\
\stackrel{\infty}{\infty} \\
\stackrel{+}{J}\end{array}$ & $\begin{array}{l}\infty \\
\infty \\
\infty \\
\stackrel{+}{ \pm} \\
=\end{array}$ & 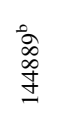 & $\begin{array}{l}\stackrel{8}{\circ} \\
\stackrel{\infty}{+}\end{array}$ \\
\hline $\begin{array}{l}0 \\
\frac{0}{\pi} \\
0 \\
0 \\
0\end{array} \mid$ & $\sum_{U}^{3}$ & 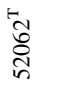 & 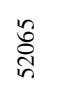 & $\begin{array}{l}\text { ț } \\
\text { ñ }\end{array}$ & के & ڤิ & $\begin{array}{r}8 \\
\text { \& } \\
1 \text { ì } \\
\text { in }\end{array}$ & 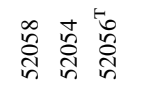 & $\vec{\circ}$ & & 蒿 & , & 蒿 & 商 & 赵 & 蔏 & 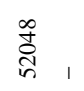 \\
\hline$\frac{\mathscr{c}}{0}$ & & $\overline{\bar{\sigma}}$ & 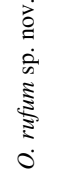 & & 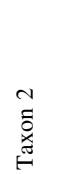 & 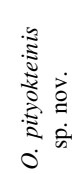 & & & & $\begin{array}{l}m \\
\tilde{\sigma} \\
\tilde{\sigma} \\
\tilde{\sigma}\end{array}$ & 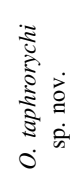 & & & & & & \\
\hline
\end{tabular}




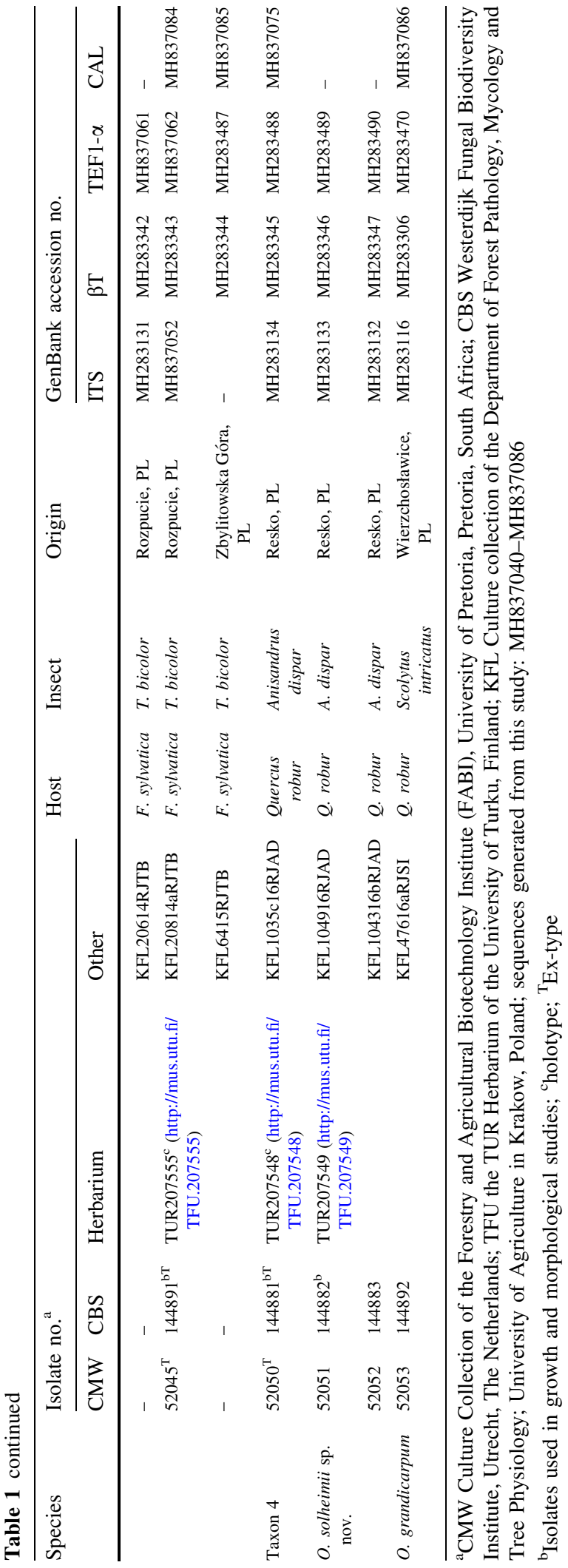

elongation factor 1-alpha (TEF1- $\alpha$ ) were amplified for sequencing and phylogenetic analyses. Primers used in this study were as follows: ITS 1-F (Gardes and Bruns 1993) and ITS4 (White et al. 1990) for the ITS region, Bt2a (Glass and Donaldson 1995) or T10 (O’Donnell and Cigelnik 1997) and Bt2b (Glass and Donaldson 1995) for $\beta$ T, CL2F and CL2R (Duong et al. 2012) for CAL, and F-728F (Carbone and Kohn 1999) and EF2 (O'Donnell et al. 1998) for TEF1- $\alpha$.

DNA fragments were amplified in a $25 \mu \mathrm{L}$ reaction mixture containing $0.25 \mu \mathrm{L}$ of Phusion High-Fidelity DNA polymerase (Finnzymes, Espoo, Finland), $5 \mu \mathrm{L}$ Phusion HF buffer $(5 \mathrm{x}), 0.5 \mu \mathrm{L}$ of dNTPs $(10 \mathrm{mM})$, $0.75 \mu \mathrm{L}$ DMSO $(100 \%)$ and $0.5 \mu \mathrm{L}$ of each primer $(25 \mu \mathrm{M})$. Amplification reactions were performed in the LabCycler Gradient thermocycler (Sensoquest Biomedical Electronics GmbH, Germany). Amplification of the various loci was performed under the following conditions: a denaturation step at $98{ }^{\circ} \mathrm{C}$ for $30 \mathrm{~s}$ was followed by 35 cycles of $5 \mathrm{~s}$ at $98{ }^{\circ} \mathrm{C}, 10 \mathrm{~s}$ at 52-64 ${ }^{\circ} \mathrm{C}$ (depending on the primer melting temperature and fungal species) and $30 \mathrm{~s}$ at $72{ }^{\circ} \mathrm{C}$, and a final elongation step at $72{ }^{\circ} \mathrm{C}$ for $8 \mathrm{~min}$. The PCR products were visualized under UV light on a $2 \%$ agarose gel stained with Midori Green DNA Stain (Nippon Genetic Europe).

Amplified products were sequenced with the BigDye $^{\circledR}$ Terminator v 3.1 Cycle Sequencing Kit (Applied Biosystems, Foster City, CA, USA) and the products were resolved with a ABI PRISM 3100 Genetic Analyzer (Applied Biosystems), at the DNA Research Centre (Poznań, Poland) using the same primers that were used for the PCR. The sequences (Table 1) were compared with sequences retrieved from GenBank using the BLASTn algorithm (Altschul et al. 1990). Newly obtained sequences were deposited in NCBI GenBank (Table 1).

\section{Phylogenetic analyses}

BLAST searches using the BLASTn algorithm were performed to retrieve similar sequences from GenBank (http://www.ncbi.nlm.nih.gov) and accession numbers for these sequences are presented in the corresponding phylogenetic trees (Figs. 2 and 3, S1S4). Datasets were curated with the Molecular Evolutionary Genetic Analysis (MEGA) v6.06 program (Tamura et al. 2013). The ITS dataset included all available sequences for reference species in 


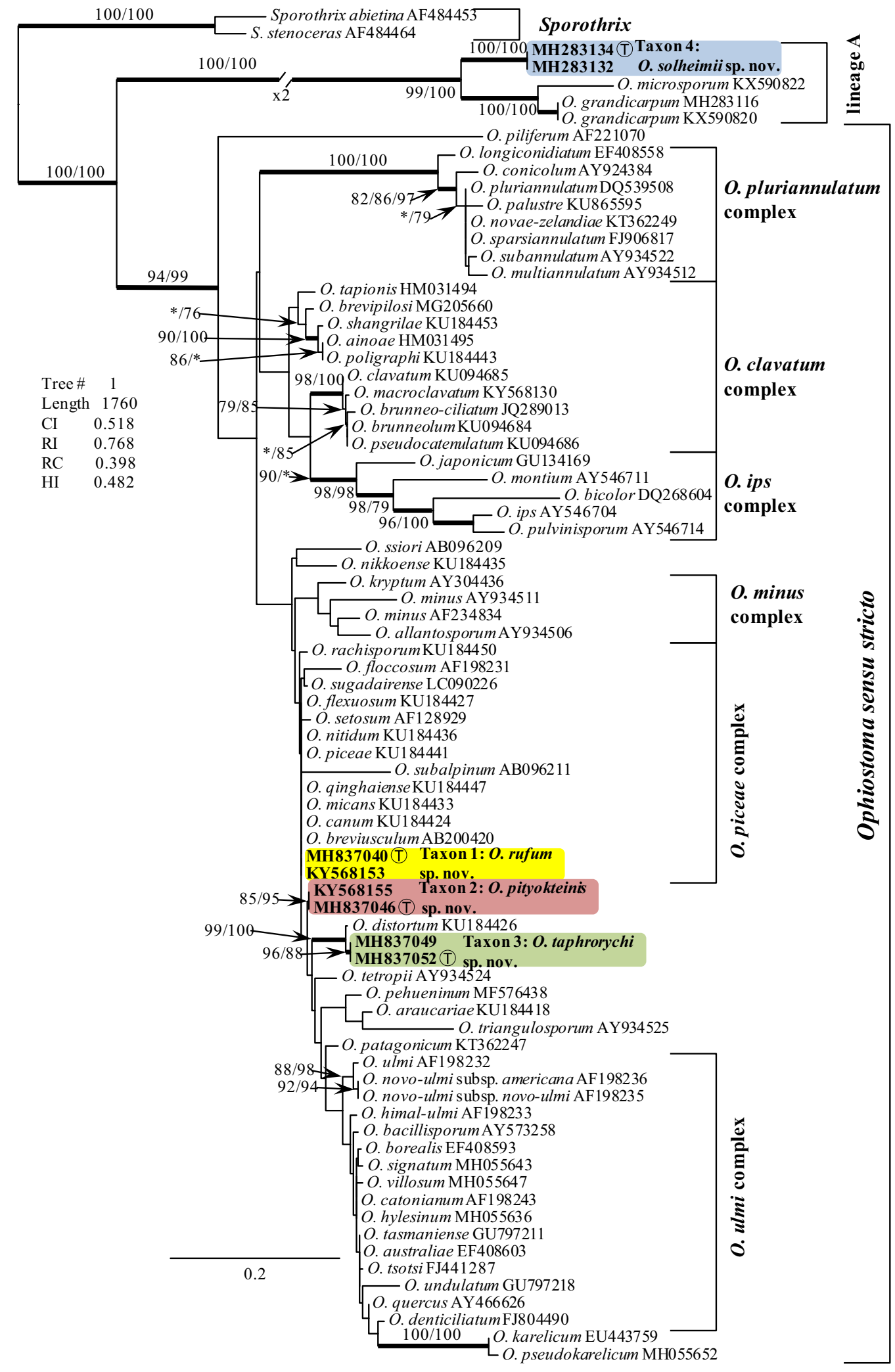


४Fig. 2 Tree topology based on ML analysis for species of Ophiostoma s. lato generated from the ITS DNA sequence data. Bootstrap values shown at nodes $\geq 75 \%$ for ML and Maximum Parsimony (MP) analyses are presented as follows: ML/MP. Bold branches indicate posterior probabilities values $\geq 0.95$ were obtained from Bayesian Inference (BI) analyses. The symbol * indicates bootstrap values $<75 \%$. The tree is drawn to scale (see bar) with branch length measured in the number of substitutions per site. Taxon 1-Ophiostoma rufum sp. nov., Taxon 2-Ophiostoma pityokteinis sp. nov., Taxon 3-Ophiostoma taphrorychi sp. nov., Taxon 4-Ophiostoma solheimii sp. nov. T-Ex-type

Fig. 3 ML based tree topology for species in the Ophiostoma piceae species complex generated from the DNA sequences of the combined (concatenated) dataset including the ITS region and three protein coding gene sequences ( $\beta T$, CAL, TEF1- $\alpha$ ). Bootstrap values $\geq 75 \%$ for ML and Maximum Parsimony (MP) analyses are presented at nodes as follows: ML/MP. Bold branches indicate posterior probabilities values $\geq 0.95$ as obtained from Bayesian Inference (BI) analyses. The symbol * indicates bootstrap values $<75 \%$. The tree is drawn to scale (see bar) with branch length measured in the number of substitutions per site. Taxon 1Ophiostoma rufum sp. nov., Taxon 2-Ophiostoma pityokteinis sp. nov., Taxon 3-Ophiostoma taphrorychi sp. nov. T-Ex-type
Ophiostoma s. lato that could be retrieved from GenBank (Fig. 2) to show the placement of our isolates within this genus. The outgroup taxon for the ITS dataset analysis was Sporothrix abietina and $S$. stenoceras. The three protein coding gene regions were sequenced for 29 ( $\beta$ T, and TEF1- $\alpha$ ) and 25 (CAL) of our isolates (Table 1). Datasets were analysed individually and with regards to the protein coding sequences as concatenated constructs. Sequence alignments were performed using the online version of MAFFT v7 (Katoh and Standley 2013). The

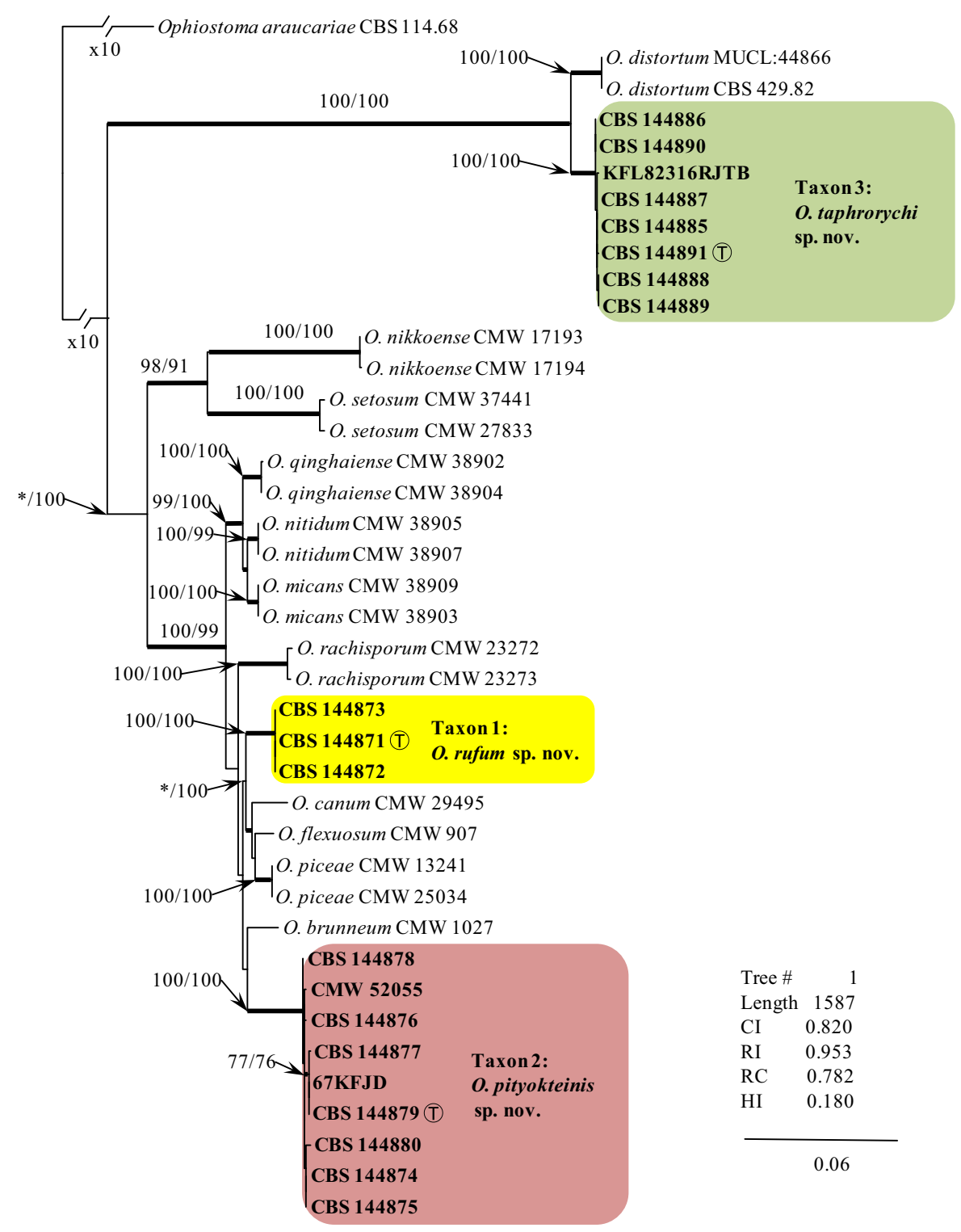


ITS, $\beta$ T, CAL and TEF1- $\alpha$ datasets were aligned using the E-INS-i strategy with a $200 \mathrm{PAM} / \kappa=2$ scoring matrix, a gap opening penalty of 1.53 and an offset value of 0.00 . The alignments were checked manually with BioEdit v.2.7.5 (Hall 1999), and for the protein coding regions the alignments were compared with gene maps previously published by Aas et al. (2018) to ensure that introns and exons were aligned appropriately. The resulting alignments and trees were deposited into TreeBASE (TB2:S24036).

Phylogenetic trees were inferred for each of the datasets using three different methods: Maximum Likelihood (ML), Maximum Parsimony (MP) and Bayesian Inference (BI). For ML and BI analyses, the best-fit substitution models for each aligned dataset were established using the corrected Akaike Information Criterion (AICc) in jModelTest 2.1.10 (Guindon and Gascuel 2003; Darriba et al. 2012). ML analyses were carried out with PhyML 3.0 (Guindon et al. 2010), utilizing the Montpelier online server (http:// www.atgc-montpellier.fr/phyml/). The ML analysis included bootstrap analysis (1000 bootstrap pseudoreplicates) in order to assess node support values and the overall reliability of the tree topology.

MP analyses were performed with PAUP* $4.0 \mathrm{~b} 10$ (Swofford 2003). Gaps were treated as fifth state characters. Bootstrap analysis (1000 bootstrap replicates) was conducted to determine the levels of confidence for the nodes within the inferred tree topologies. Tree bisection and reconnection (TBR) was selected as the branch swapping option. The tree length (TL), Consistency Index (CI), Retention Index (RI), Homoplasy Index (HI) and Rescaled Consistency Index (RC) were recorded for each analysed dataset after the trees were generated.

BI analyses using Markov Chain Monte Carlo (MCMC) methods were carried out with MrBayes v3.1.2 (Ronquist and Huelsenbeck 2003). The four MCMC chains were run for 10 million generations applying the best-fit model. Trees were sampled every 100 generations, resulting in 100,000 trees. The Tracer v1.4.1 program (Rambaut and Drummond 2007) was utilized to determine the burn-in value for each dataset. The remaining trees were utilized to generate a $50 \%$ majority rule consensus tree, which allowed for calculating posterior probability values for the nodes.
Morphology, growth studies and mating tests

Morphological characters were examined for selected isolates and for the herbarium specimens chosen to represent the type specimens for the newly proposed species. Cultures were grown on 2\% MEA with or without host tree twigs to induce potential ascocarp formation. Autoclaved twigs with bark were positioned in the centre of the MEA agar plates. Fungal cultures were derived from single spores, and crossings were made following the technique described by Grobbelaar et al. (2010). To encourage the production of ascomata for species descriptions, single conidial isolates were crossed in all possible combinations. Cultures were incubated at $25^{\circ} \mathrm{C}$ and monitored regularly for the appearance of fruiting structures.

Morphological features were examined by mounting materials in $80 \%$ lactic acid on glass slides, and observing various fruiting structures using a Nikon Eclipse $50 i$ microscope (Nikon ${ }^{\circledR}$ Corporation, Tokyo, Japan) with an Invenio 5S digital camera (DeltaPix ${ }^{\circledR}$, Maalov, Denmark) to capture photographic images. Microscopy was done as previously described by Kamgan Nkuekam et al. (2011). Colour designations were based on the charts of Kornerup and Wanscher (1978).

For each taxonomically relevant structure fifty measurements were made, whenever possible, with the Coolview 1.6.0 software (Precoptic ${ }^{\circledR}$, Warsaw, Poland). Averages, ranges and standard deviations were calculated for the measurements, and these are presented in the format '(min-)(mean - SD)$($ mean $+\mathrm{SD})(-\max )^{\prime}$.

Growth characteristics for the four newly proposed species were determined by analysing the radial growth for four isolates in pure culture that represent each of the studied species (Table 1). Agar disks (5 mm diam.) were cut from actively growing margins of fungal colonies for each of the tested isolates and these disks were placed in the centre of plates containing 2\% MEA. Four replicate plates for each of the isolates studied were incubated at 5, 10, 15, 20, 25, 30 and $35^{\circ} \mathrm{C}$. Colony diameters (two measurements per plate) were determined $7 \mathrm{~d}$ after inoculation and radial growth rates were calculated as $\mathrm{mm} / \mathrm{d}$. 


\section{Results}

\section{Morphological characteristics}

The four new taxa showed differences with regards to growth rates in culture and colour differences ranging from rust brown, grey brown, to olive brown (Table 2). Taxon 1 and Taxon 2 produced abundant synnemata that were arranged either singly or in groups topped with cream-white mucilaginous spore drops. A sporothrix-like synanamorph was also present in cultures of Taxon 1. In addition, Taxon 3 and

Table 2 Morphological comparisons of the novel taxa

\begin{tabular}{|c|c|c|c|c|}
\hline Species & Taxon 1 & Taxon 2 & Taxon 3 & Taxon 4 \\
\hline Sexual state & \multirow[t]{6}{*}{ Unknown } & \multirow[t]{6}{*}{ Unknown } & Present & Present \\
\hline Ascomata base & & & $(62-) 88-130(-169)$ & $(299-) 329-457(-548)$ \\
\hline $\begin{array}{l}\text { Ascomatal neck length } \\
(\mu \mathrm{m})\end{array}$ & & & $(347-) 444-559(-632)$ & $\begin{array}{l}(1192-) 1627-2218 \\
(-2569)\end{array}$ \\
\hline Ascospore shape & & & $\begin{array}{l}\text { Allantoid in side view, } \\
\text { elliptical in front view }\end{array}$ & Orange-section \\
\hline $\begin{array}{l}\text { Ascospore size } \\
\text { excluding sheath (in } \\
\text { side view, } \mu \mathrm{m} \text { ) }\end{array}$ & & & $\begin{array}{l}(2.8-) 3-3.6(-4) \times(0.8-) \\
\quad 1-1.3(-1.5)\end{array}$ & $\begin{array}{l}(2.5-) 2.6-3.1 \\
(-3.5) \times(0.8-) \\
1.1-1.4(-1.6)\end{array}$ \\
\hline $\begin{array}{l}\text { Ascospore size } \\
\text { excluding sheath (in } \\
\text { side view, } \mu \mathrm{m} \text { ) }\end{array}$ & & & $\begin{array}{l}(2.8-) 3.1-3.7 \\
(-4) \times(1-) 1.1- \\
1.5(-1.7)\end{array}$ & $\begin{array}{l}(2.3-) 2.7-3.2 \\
(-3.8) \times(0.8-) \\
1.1-1.6(-1.9)\end{array}$ \\
\hline Asexual state & $\begin{array}{l}\text { Pesotum-like, } \\
\text { sporothrix- } \\
\text { like }\end{array}$ & Pesotum-like & Hyalorhinocladiella-like & $\begin{array}{l}\text { Hyalorhinocladiella- } \\
\text { like }\end{array}$ \\
\hline Synnematal length $(\mu \mathrm{m})$ & $\begin{array}{l}(261-) \\
506-1001 \\
(-1183)\end{array}$ & $(187-) 265-511(-698)$ & - & - \\
\hline Conidial shape & $\begin{array}{l}\text { Oblong to } \\
\text { curved }\end{array}$ & Obovoid & $\begin{array}{l}\text { Oblong elliptical, obovoid to } \\
\text { bacilliform, sometimes } \\
\text { allantoid }\end{array}$ & $\begin{array}{l}\text { Allantoid in side } \\
\text { view; ellipsoidal in } \\
\text { face view }\end{array}$ \\
\hline Conidial size $(\mu \mathrm{m})$ & $\begin{array}{l}(2.5-) 3.3-4.5 \\
\quad(-6.2) \times \\
(1.2-) \\
1.4-1.7 \\
(-2.2)\end{array}$ & $\begin{array}{l}(3.2-) 3.5-4.1 \\
(-4.5) \times(0.9-) \\
1.2-1.6(-1.8)\end{array}$ & $\begin{array}{l}(3.3-) 4.2-5.4 \\
(-6.6) \times(0.8-) \\
0.9-1.3(-1.7)\end{array}$ & $\begin{array}{l}\text { allantoid: }(2.9- \\
\quad 3.7-5.1 \\
(-6.3) \\
\times(0.8-) 1.1-1.7 \\
(-2.2) ; \text { ellipsoidal: } \\
(3.1-) 3.9-4.8 \\
(-5.3) \times(0.9-) \\
1.2-1.8(-2.1)\end{array}$ \\
\hline Growth rate $\left(\mathrm{mm} \mathrm{d}^{-1}\right)$ & $2.2( \pm 0.1)$ & $3.9( \pm 0.1)$ & $4.2( \pm 0.1)$ & $4.0( \pm 0.1)$ \\
\hline $\begin{array}{l}\text { Optimal growth temp on } \\
\text { MEA }\end{array}$ & $25^{\circ} \mathrm{C}$ & $25^{\circ} \mathrm{C}$ & $20{ }^{\circ} \mathrm{C}$ & $25^{\circ} \mathrm{C}$ \\
\hline Colony colour & $\begin{array}{l}\text { Brownish } \\
\text { orange to a } \\
\text { rust brown }\end{array}$ & Coffee to dark brown & Brown & Olive brown \\
\hline Habitat & $\begin{array}{l}\text { Coniferous } \\
\text { forest }\end{array}$ & Coniferous forest & Hardwood forest & Hardwood forest \\
\hline Host & L. decidua & A. alba & Fagus sylvatica & Quercus robur \\
\hline Insect & Ips cembrae & $\begin{array}{l}\text { Pityokteines curvidens, } \\
\text { Pityokteines vorontzowi, } \\
\text { Cryphalus piceae }\end{array}$ & Taphrorychus bicolor & Anisandrus dispar \\
\hline Distribution & $\begin{array}{l}\text { Czech } \\
\text { Republic }\end{array}$ & Poland & Poland & Poland \\
\hline
\end{tabular}




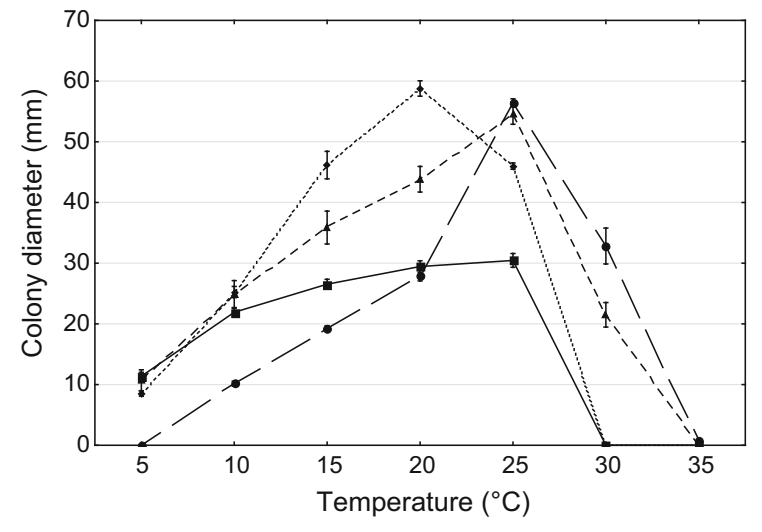

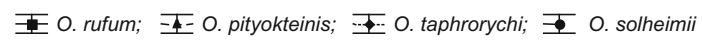

Fig. 4 Comparison of mean growth on MEA (two isolates per tested species, \pm standard deviation) of Taxa 1-4 held at different temperatures (grown $7 \mathrm{~d}$ in the dark)

Taxon 4 produced hyalorhinocladiella-like asexual morphs. A sexual state was induced in Taxon 3 and 4. Sexual states were not observed for Taxon 1 and Taxon 2 in any of the crosses done between different isolates. Morphological differences among these new taxa are listed in Table 2, and discussed in the Notes under the new species descriptions in the Taxonomy section.

The optimal growth temperature for Taxon 3 was at $20^{\circ} \mathrm{C}$, and at $25^{\circ} \mathrm{C}$ for Taxon 1,2 and 4 . For all isolates the growth rate was minimal at $5{ }^{\circ} \mathrm{C}$ except for Taxon 4 which failed to grow at this temperature. No growth was observed at $30{ }^{\circ} \mathrm{C}$ for Taxon 1 and 3 and all Taxa failed to grow at $35^{\circ} \mathrm{C}$ except for Taxon 4 (Fig. 4).

\section{Phylogenetic analyses}

Alignments for the ITS, $\beta$ T, CAL, TEF1- $\alpha$ sequences and the concatenated combined dataset contained 759 , 400 (for $\beta \mathrm{T}$ O. piceae species complex), 503 (for $\beta \mathrm{T}$ lineage A), 936, 755 (for TEF1- $\alpha$ O. piceae species complex), 643 (for TEF1- $\alpha$ lineage A) and 2356 characters (including gaps), respectively. The exon/ intron arrangement of the $\beta \mathrm{T} O$. piceae species complex data included exons 3,4 , and $5 / 6$, interrupted with introns 3 and 4 , but lacking intron 5. The exon/ intron arrangement of the $\beta \mathrm{T}$ lineage A data included exons $3,4 / 5$, and 6 , interrupted with introns 2,3 and 5 , but lacking intron 4 . The aligned TEF1- $\alpha$ gene region consisted of intron 3 and exons 4/5/6, while lacking introns 4 and 5 . The alignment of the CAL dataset contained exons 2, 3, 4 and 5/6, interrupted with introns 2, 3, 4 and 6, while lacking intron 5 .

The best evolutionary substitution model for ITS, $\beta$ T, CAL, TEF1- $\alpha$ datasets was GTR + G. Except for the TEF1- $\alpha$ for lineage A dataset, for which the best model was GTR + I. The best evolutionary substitution model for the combined ITS, $\beta$ T, CAL, TEF1- $\alpha$ datasets was GTR $+\mathrm{I}+\mathrm{G}$. The burn-in values in BI analyses for all data matrices were $25 \%$ of the trees.

The ITS tree shows the placement of the Czech and Polish isolates (referred to as Taxon 1 to Taxon 4) within the Ophiostomatales (Fig. 2). Taxa 1-3 resided among sequences representing species that are members of Ophiostoma s. stricto, while Taxon 4 is grouped with other species in the lineage A (Fig. 2) (De Beer et al. 2016). Taxa 1-3 appear to group closely with members of the $O$. piceae species complex. Taxon 1 grouped within the $O$. piceae species complex, while Taxa 2 and 3 formed two adjacent lineages peripheral to the $O$. piceae species complex (Fig. 2). The lineage that includes Taxon 3 includes the ex-type isolate of $O$. distortum (Fig. 2). Strains of Taxon 1 had ITS sequences that were identical with ITS sequences noted in most members of the $O$. piceae species complex. Taxon 4 grouped among members of the lineage A, which includes $O$. grandicarpum and $O$. microsporum (Fig. 2). This taxon had unique ITS sequences compared with $O$. grandicarpum and $O$. microsporum.

The BI, MP, ML phylogenetic analyses of the aligned protein-coding datasets $(\beta \mathrm{T}, \mathrm{CAL}, \mathrm{TEF} 1-\alpha$ and combined) for members of the $O$. piceae species complex yielded trees with different topologies (Fig. 3, Figs. S1-S3). In the $\beta$ T, CAL and TEF1- $\alpha$ trees (Figs. S1-S3), Taxa 1-3 formed well-supported lineages that clearly separated these four newly proposed species from all the other known species in the $O$. piceae species complex and other closely related species. The only exception was Taxon 3, which had differences in the $\beta \mathrm{T}$ sequence compared to the $O$. distortum $\beta \mathrm{T}$ sequence, but the node lacked statistical support (Fig. S1). However, the combined analyses of the $\beta \mathrm{T}, \mathrm{CAL}$ and TEF1- $\alpha$ datasets clearly distinguish Taxa 1-3 into separate lineages within Ophiostoma s. stricto (Fig. 3). Analyses of the $\beta \mathrm{T}$, CAL and TEF1- $\alpha$ data grouped isolates of Taxon 4 in lineage A together with $O$. macrosporum and $O$. grandicarpum $(\beta \mathrm{T})$ and $O$. grandicarpum (CAL and TEF1- $\alpha$ ), corresponding to the ITS tree. This taxon 
formed a well-supported lineage that is clearly distinct from O. macrosporum and O. grandicarpum (Fig. S4).

\section{Taxonomy}

The morphological characterization and phylogenetic comparisons based on four genetic loci, showed that four taxa associated with bark beetles from the Czech Republic and Poland (Taxa 1 to 4) are distinct from each other and from other known taxa in Ophiostoma s. lato and, therefore, are described here as new species. They are described as follows:

\section{Taxon 1}

Ophiostoma rufum R. Jankowiak \& P. Bilański, sp. nov. (Figure 5) MycoBank: MB830195.

Etymology: The epithet rufum, referring to the rust brown colony on MEA.

Sexual state not observed. Asexual states: pesotumlike and sporothrix-like. Pesotum-like: Conidiophores macronematous, synnematous, abundant in culture, synnemata occurring singly or in groups (261-) 506-1001(-1183) $\mu \mathrm{m}$ long including conidiogenous apparatus (Fig. 5a, b). Stipe expanding towards both the apex and the base, dark brown at base, becoming paler toward apex (194-)422-881(-1018) $\mu \mathrm{m}$ long
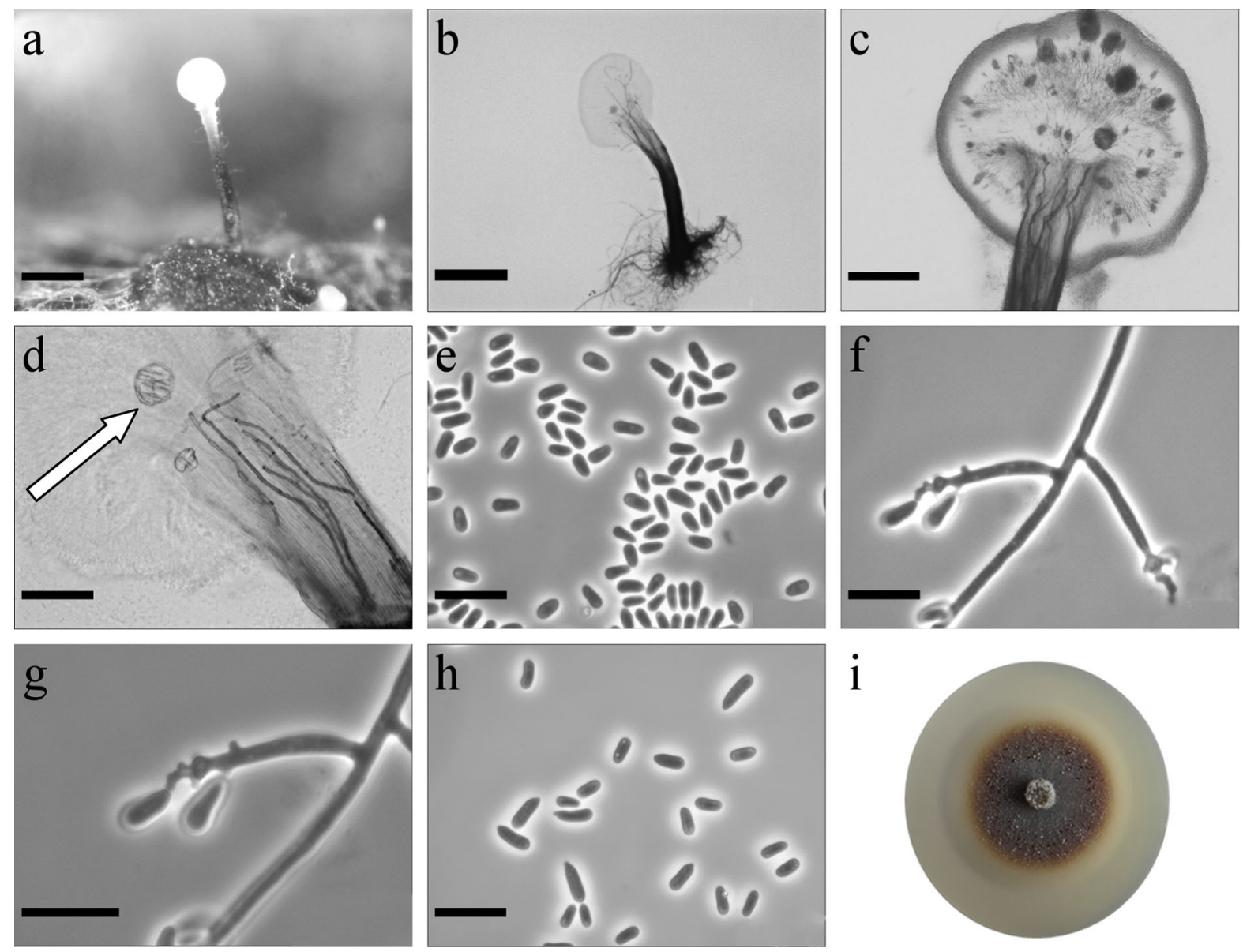

Fig. 5 Morphological characters of Ophiostoma rufum sp. nov. (CBS 144871, Taxon 1). a Synnematous asexual state on wood tissue; b conidiophores; c conidiogeneous apparatus, arrow shows crystal-like structures; d conidiogeneous cells, arrow shows crystal-like structures; e conidia; $\mathbf{f}, \mathbf{g}$ conidiophore of sporothrix-like asexual state with denticles of conidiogenous cell; $\mathbf{h}$ primary and secondary conidia; $\mathbf{i}$ fourteen-day-old culture on MEA. Scale bars: $\mathbf{a}=250 \mu \mathrm{m}, \quad \mathbf{b}=250 \mu \mathrm{m}$, $\mathbf{c}=100 \mu \mathrm{m}, \mathbf{d}=50 \mu \mathrm{m}, \mathbf{e}=10 \mu \mathrm{m}, \mathbf{f}=10 \mu \mathrm{m}, \mathbf{g}=10 \mu \mathrm{m}$, $\mathbf{h}=10 \mu \mathrm{m}$ 
(26-)32-64(-116) $\mu \mathrm{m}$ wide at base, and (36)37-117(-247) $\mu \mathrm{m}$ wide at apex. Crystal-like structures often occur in the upper part of the stipe (Fig. 5c d). Conidiogenous cells (8-)12.5-19.3(-24) $\times(1.4-$ )1.5-1.9(-2) $\mu \mathrm{m}$ (Fig. 5 d). Conidia hyaline, onecelled, smooth, oblong, sometimes slightly curved (2.5-)3.3-4.5(-6.2) × (1.2-)1.4-1.7(-2.2) $\mu \mathrm{m}$ aggregating into a cream-white mucilaginous spore drop (Fig. 5e). Synnematous asexual morphs frequently observed on different agar media with larch twigs. Asexual morph attached to substrate by brown rhizoidlike hyphae.

Sporothrix-like Conidiophores mononematous, micronematous, hyaline (4-)14.7-45.1(-80) $\mu \mathrm{m}$ long and (1.6-)2-2.6(-3) $\mu \mathrm{m}$ wide at the base, denticulate giving rise to primary conidia (Fig. 5f, g). Denticles terminated. Primary conidia non-septate, hyaline, clavate or fusiform (7.2-)8.9-12.4(-15.2) $\times(2-$ )2.5-3.1(-3.4) $\mu \mathrm{m}$, sometimes producing denticles and giving rise to secondary conidia. Secondary conidia hyaline, smooth, one-celled, obovoid with a pointed base, sometimes slight curved (2-)4.5-6.7(8) $\times(1.8-) 1.9-2.5(-2.8) \mu \mathrm{m}$ (Fig. 5h).

Culture characteristics Colonies with optimal growth at $25{ }^{\circ} \mathrm{C}$ on $2 \%$ MEA with radial growth rate $2.2( \pm 0.1) \mathrm{mm} / \mathrm{d}$, no growth occurred at 30 and $35{ }^{\circ} \mathrm{C}$. Colonies brownish orange to a rust brown, with smooth margins (Fig. 5i). Reverse rust brown. Hyphae pale yellow to olive yellow in colour (Kornerup and Wanscher 1978), smooth, submerged in the medium and aerial mycelium abundant, not constricted at the septa, 0.6-5.3 (mean $1.8 \pm 1.3$ ) $\mu \mathrm{m}$ diam.

Habitat: coniferous forest dominated by Larix decidua

Host tree: Larix decidua

Insect vectors: Ips cembrae

Distribution: Czech Republic

Type material CZECH REPUBLIC, Albrechtice, in coniferous forest dominated by L. decidua, from Ips cembrae galleries established on L. decidua, collector K. Lukášová, 12 May 2014. Holotype dried specimen TUR 207541 (http://mus.utu.fi/TFU.207541), exholotype living culture CBS 144871 = CMW 52062.

Notes This species is most closely related to $O$. breviusculum (Chung et al. 2006) based on the phylogenetic analyses of the ITS, and $\beta$ T sequences (Figs. 2, S1). However, the DNA sequences of $\beta$ T and TEF1- $\alpha$ (Figs. S1, S2) are unique and clearly suggested that $O$. rufum is distinct from $O$. breviusculum, and other species of the $O$. piceae species complex.

Morphologically, O. breviusculum can be distinguished from this new species by having shorter synnemata. Ophiostoma rufum differs from $O$. breviusculum by the presence of crystal-like structures in the upper part of the stipe. In addition, $O$. breviusculum forms brown to dark brown colonies, while the new taxon has colonies displaying brownish orange to rust brown colours.

Ophiostoma rufum was infrequently isolated from L. decidua in association with Ips cembrae in Czech Republic (Jankowiak et al. 2017a).

\section{Taxon 2}

Ophiostoma pityokteinis R. Jankowiak \& P. Bilański, sp. nov. (Fig. 6). MycoBank: MB830196

Etymology The epithet pityokteinis reflects the genus name of the bark beetle vector for this fungus, Pityokteines.

Sexual state not observed. Asexual states: pesotumlike. Conidiophores macronematous, synnematous, abundant in culture and sterilized fir twigs (187265-511(-698) $\mu \mathrm{m}$ long including conidiogenous apparatus, synnemata occurring singly or in groups, stipe well or poorly developed, light or dark pigmented, mostly expanding towards the apex, cup-or club shaped (101-)133-319(-481) $\mu \mathrm{m}$ long (26)51-122(-169) $\mu \mathrm{m}$ wide at base, and (29-)50-167(302) $\mu \mathrm{m}$ wide at apex (Fig. 6a-f). Conidiogenous cells discrete, terminal, hyaline, cylindrical (11.1)15-30.7(-40.6) × (0.6-)0.9-1.3(-1.5) $\mu \mathrm{m} \quad$ (Fig. 6 g). Conidia hyaline, one-celled, obovoid (3.2)3.5-4.1(-4.5) × (0.9-)1.2-1.6(-1.8) $\mu \mathrm{m}$ aggregating into a cream-white mucilaginous spore drop (Fig. 6h). Synnemata anamorph attached to substrate by brown rhizoid-like hyphae (Fig. 6c).

Culture characteristics Optimal growth temperature on MEA is $25{ }^{\circ} \mathrm{C}$ with radial growth rate of 3.9 $( \pm 0.1) \mathrm{mm} / \mathrm{d}$, no growth occurred at $35^{\circ} \mathrm{C}$. Colonies on MEA hyaline at first, later becoming coffee to dark brown in colour, floccose, with abundant grey aerial mycelium, margin smooth (Fig. 6i). Reverse dark brown. Hyphae light to dark brown in colour (Kornerup and Wanscher 1978), smooth, often fused, submerged in the medium and aerial mycelium 

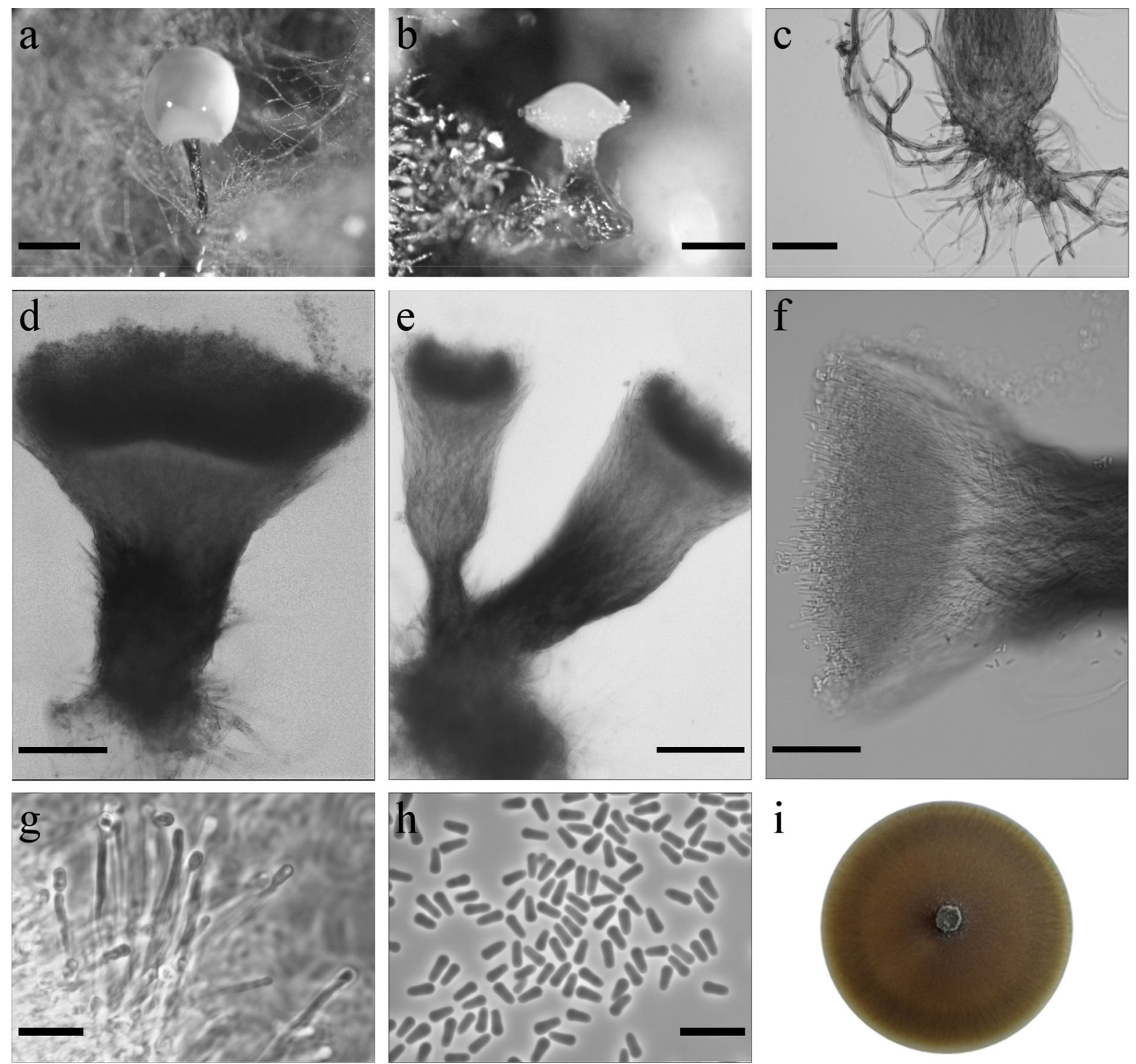

Fig. 6 Morphological characters of Ophiostoma pityokteinis sp. nov. (CBS 144879, Taxon 2). a, b Synnematous asexual state on wood tissue; c rhizoid-like hyphae of synnemata anamorph; d-f conidiophores; $\mathbf{g}$ conidiogeneous cells; $\mathbf{h}$ conidia;

abundant, not constricted at the septa, 0.8-5.4 (mean $1.8 \pm 1) \mu \mathrm{m}$ diam.

Habitat: coniferous forest dominated by Abies alba Host tree: Abies alba

Insect vectors: Pityokteines curvidens, Pityokteines vorontzowi, Cryphalus piceae (Jankowiak et al. 2017a)

Distribution: Poland (i) fourteen-day-old culture on MEA. Scale bars: $\mathbf{a}=250 \mu \mathrm{m}$, $\mathbf{b}=250 \mu \mathrm{m}, \mathbf{c}=50 \mu \mathrm{m}, \mathbf{d}=100 \mu \mathrm{m}, \mathbf{e}=100 \mu \mathrm{m}, \mathbf{f}=50 \mu \mathrm{m}$, $\mathbf{g}=10 \mu \mathrm{m}, \mathbf{h}=10 \mu \mathrm{m}$

Type material POLAND, Nawojowa, in coniferous forest dominated by $A$. alba, from Pityokteines curvidens beetles infesting A. alba, collector P. Majka, 17 June 2013. Holotype dried specimen TUR 207546 (http://mus.utu.fi/TFU.207546), ex-holotype living culture CBS 144879 = CMW 52056.

Notes This species forms a lineage within Ophiostoma s. stricto and can be distinguished from all its 
members by the ITS (Fig. 2) and protein coding sequences (Figs. S1-S3).

Morphologically, O. pityokteinis is most similar to members of the $O$. piceae species complex. In contrast to the species in the $O$. piceae species complex, which produce column-like synnemata, $O$. pityokteinis produces cup- or club-like synnemata. In addition, this species has no sporothrix-like asexual state, which is a characteristic for many species of the $O$. piceae species complex.

Ophiostoma pityokteinis has very specific host and vector ranges. It was found abundantly on A. alba in associations with fir-infesting bark beetles, especially Pityokteines species (Jankowiak et al. 2017a).

\section{Taxon 3}

Ophiostoma taphrorychi B. Strzałka \& R. Jankowiak, sp. nov. (Figure 7) MycoBank: MB830197

Etymology The epithet taphrorychi reflects the genus name of the bark beetle vector of this fungus, T. bicolor.

Sexual state present Ascomata abundantly produced on media and sterilized beech twigs, bases black, globose, verrucose (62-)88-130(-169) $\mu \mathrm{m}$ diam., ornamented with brown hyphal hairs of variable length, 5 to $77 \mu \mathrm{m}$ long and $2.1-3.3 \mu \mathrm{m}$ wide at the base (Fig. 7a-c). Necks black, straight or slightly curved, sometimes with paler bumps, often extended at the base (347-)444-559(-632) $\mu \mathrm{m}$ long with annuli absent or occasionally 1-2 present (Fig. $7 d$ ). Diameter of the necks (10.8-)11.8-14.5(-15.4) $\mu \mathrm{m}$ at the apex and (24.6-)29-41.5(49.3) $\mu \mathrm{m}$ at the base. Ostiolar hyphae present, pigmented, aseptate, straight, tapering towards the apex (8-)8-12(-15) in number (18.5)27.7-36.6(-40) $\mu \mathrm{m}$ long (1.2-)1.4-1.7(-1.8) $\mu \mathrm{m}$ at the apex and (2.1-)2.4-3.2-(3.6) $\mu \mathrm{m}$ at the base, sometimes formed below the apex (Fig. 7e, f). Asci not observed. Ascospores one-celled, allantoid in side view (2.8-)3-3.6(-4) $\times(0.8-) 1-1.3(-1.5) \mu \mathrm{m}$, elliptical in front view $(2.8-) 3.1-3.7(-4) \times(1-) 1.1-1.5(-$ 1.7) $\mu \mathrm{m}$ and circular in end view to $1.8($ mean $1.5 \mu \mathrm{m})$, with residual sheath up to $1 \mu \mathrm{m}$ thick, accumulated in white-coloured mass at the tip of the neck (Fig. $7 \mathrm{~g}$ ).

Asexual state: hyalorhinocladiella-like. Conidiophores mononematous, micronematous, hyaline (9)11-19(-26) × 1-1.5 $\mu \mathrm{m}$ (Fig. 7h-j). Conidia hyaline, smooth, oblong elliptical, obovoid to bacilliform, sometimes allantoid (3.3-)4.2-5.4(-6.6) $\times(0.8-$
)0.9-1.3(-1.7) $-1.5 \mu \mathrm{m}$. Sometimes conidia were formed from primary conidia. Primary conidia nonseptate, hyaline, clavate (6.7-)7.9-11.1(13.6) $\times(1.3-) 1.6-2.3(-2.8) \mu \mathrm{m}$, sometimes producing denticles and giving rise to secondary conidia (Fig. 7k).

Culture characteristics Colonies with optimal growth at $20{ }^{\circ} \mathrm{C}$ on $2 \%$ MEA with a radial growth rate at $4.2( \pm 0.1) \mathrm{mm} / \mathrm{d}$; growth at $15{ }^{\circ} \mathrm{C}$ was better when compared to growth at $25^{\circ} \mathrm{C}$, and no growth occurred at 30 and $35{ }^{\circ} \mathrm{C}$. Colonies brown, margins smooth (Fig. 71). Reverse dark brown. Hyphae olive yellow in colour (Kornerup and Wanscher 1978), smooth, submerged in the medium and aerial light greyish mycelium sparse, not constricted at the septa, 0.9-4.9 (mean $2.3 \pm 1.1$ ) $\mu \mathrm{m}$ diam.

Habitat: hardwood forest dominated by Fagus sylvatica

Host tree: Fagus sylvatica

Insect vectors: Taphrorychus bicolor

Distribution: Poland

Type material POLAND, Rozpucie, in hardwood forest dominated by $F$. sylvatica, from $T$. bicolor beetles infesting $F$. sylvatica, collector $P$. Bilański, 2 June 2016. Holotype dried specimen TUR 207555 (http://mus.utu.fi/TFU.207555), ex-holotype living culture CBS 144891 = CMW 52045.

Notes This species is most closely related to $O$. distortum (Davidson, 1971). However, the DNA sequences of ITS, $\beta$ T, CAL and TEF1- $\alpha$ (Figs. 2, $\mathrm{S} 1-\mathrm{S} 3$ ) clearly suggested that $O$. taphrorychi is distinct from $O$. distortum.

Ophiostoma taphrorychi morphologically resembles $O$. torulosum, which was described from $T$. domesticum on $F$. sylvatica in Germany (Butin and Zimmermann 1972). However, it can be distinguished from $O$. torulosum by smaller ascospores, and the presence of a different asexual state. Ophiostoma torulosum produces sporothrix-like asexual state, while the new species has a hyalorhinocladiella-like morph producing larger primary and in some instances secondary conidia. In addition, O. taphrorychi was isolated only from T. bicolor (Jankowiak et al. 2019), suggesting a specific association with this bark beetle species. 

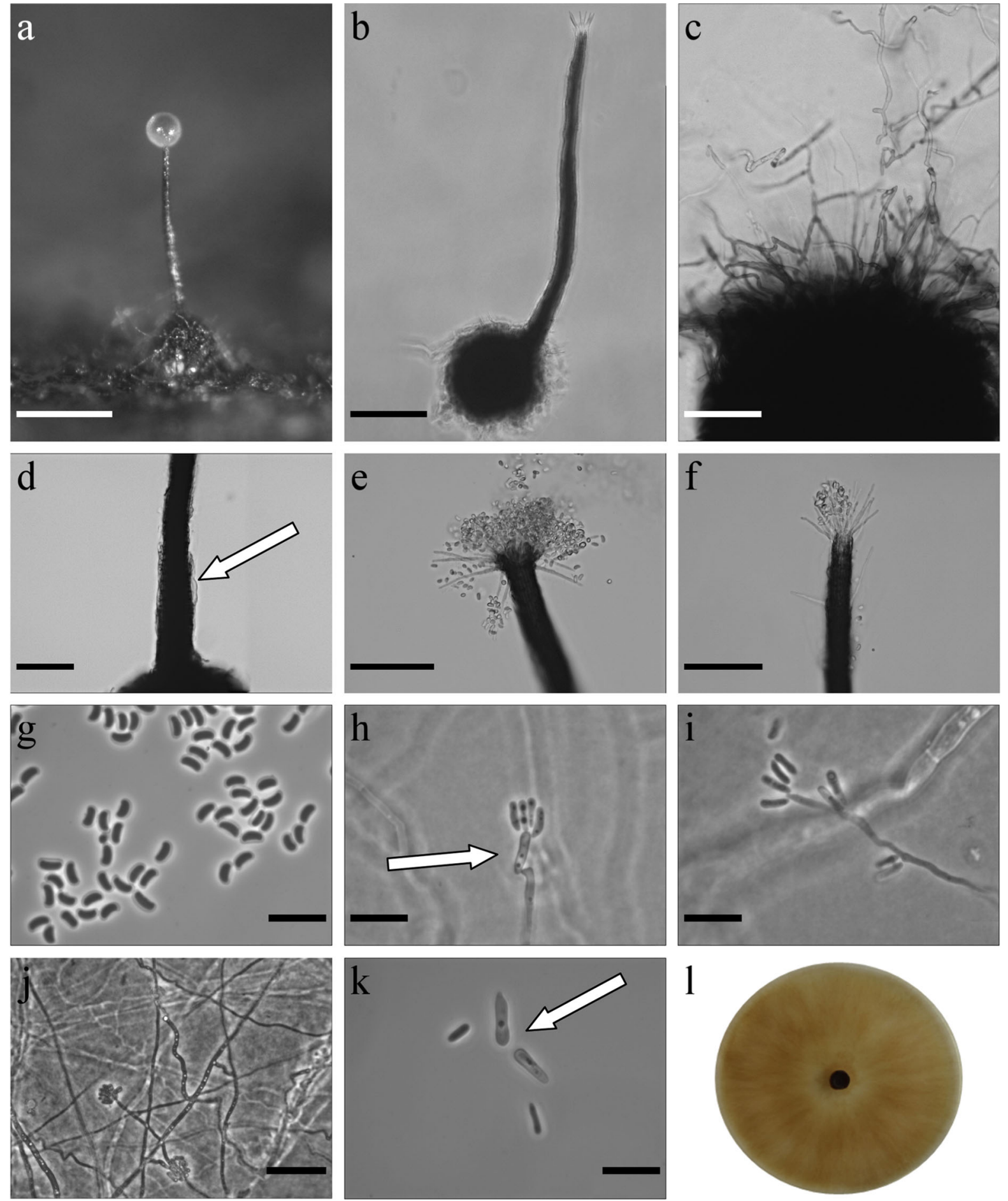

Fig. 7 Morphological characters of Ophiostoma taphrorychi sp. nov. (CBS 144891, Taxon 3). a Ascoma on wood tissue; b ascoma; c ascomatal base; $\mathbf{d}$ base of neck, arrow shows paler bumps; e, $\mathbf{f}$ top of neck with ostiolar hyphae $\mathbf{g}$ ascospores; $\mathbf{h}-$ $\mathbf{j}$ conidiophore of hyalorhinocladiella-like asexual state, arrow indicates primary conidium; k primary (arrow) and secondary conidia; l fourteen-day-old culture on MEA. Scale bars: $\mathbf{a}=250 \mu \mathrm{m}, \mathbf{b}=100 \mu \mathrm{m}, \mathbf{c}=50 \mu \mathrm{m}, \mathbf{d}=50 \mu \mathrm{m}, \mathbf{e}=50 \mu \mathrm{m}$, $\mathbf{f}=50 \mu \mathrm{m}, \mathbf{g}=10 \mu \mathrm{m}, \mathbf{h}=10 \mu \mathrm{m}, \quad \mathbf{i}=10 \mu \mathrm{m}, \mathbf{j}=25 \mu \mathrm{m}$, $\mathbf{k}=10 \mu \mathrm{m}$ 

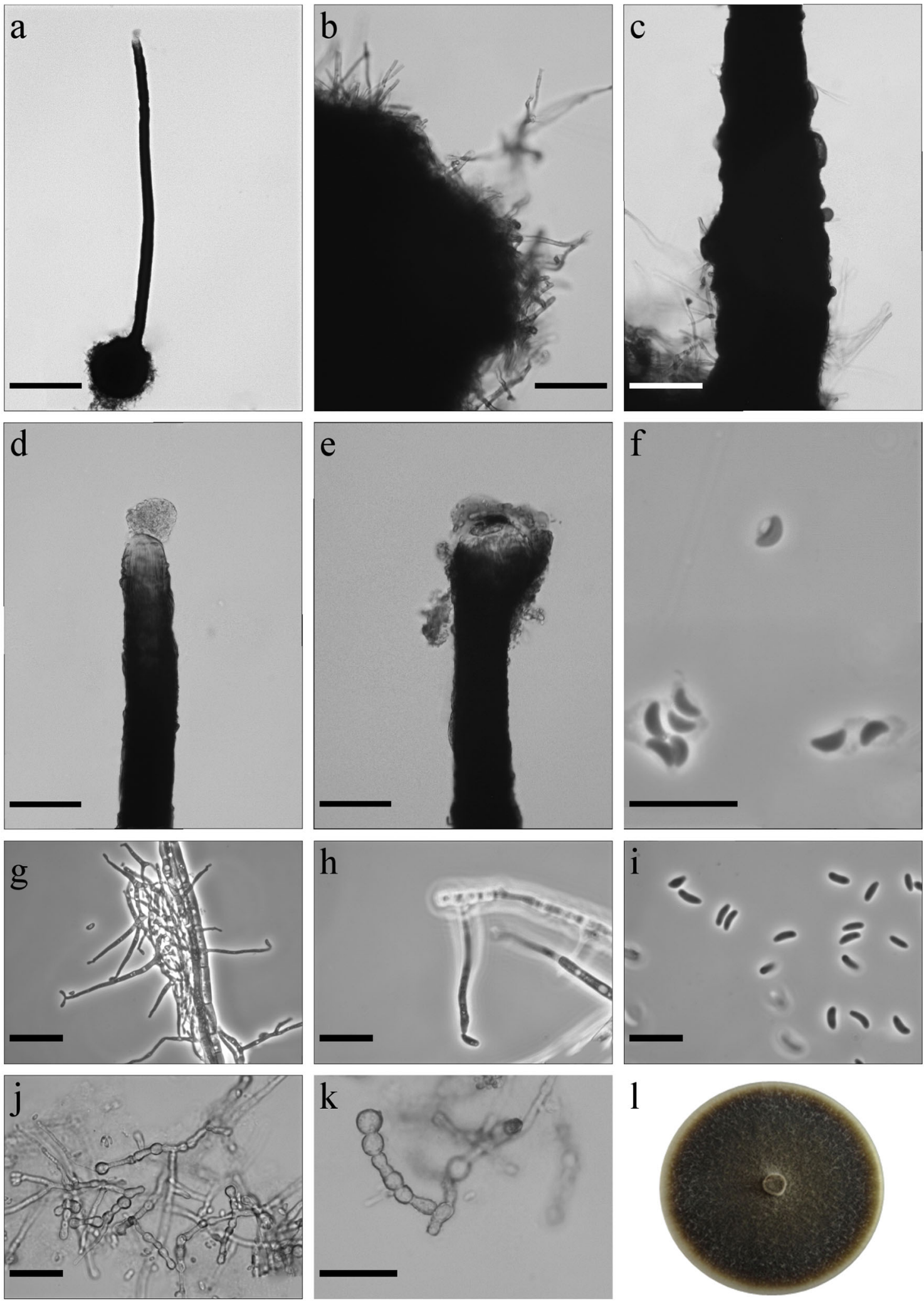
४Fig. 8 Morphological characters of Ophiostoma solheimii sp. nov. (CBS 144881, Taxon 4). a Ascoma; b ascomatal base; c base of neck with bumps; d top of neck without ostiolar hyphae; e cup-shaped opening at the apex of neck; f ascospores; $\mathbf{g}, \mathbf{h}$ conidiophore of hyalorhinocladiella-like asexual state; i conidia; j, k chlamydospores-like cells; l fourteen-day-old culture on MEA. Scale bars: $\mathbf{a}=250 \mu \mathrm{m}, \quad \mathbf{b}=50 \mu \mathrm{m}$, $\mathbf{c}=50 \mu \mathrm{m}, \mathbf{d}=50 \mu \mathrm{m}, \mathbf{e}=50 \mu \mathrm{m}, \mathbf{f}=10 \mu \mathrm{m}, \mathbf{g}=25 \mu \mathrm{m}$, $\mathbf{h}=10 \mu \mathrm{m}, \mathbf{i}=10 \mu \mathrm{m}, \mathbf{j}=25 \mu \mathrm{m}, \mathbf{k}=25 \mu \mathrm{m}$

\section{Taxon 4}

Ophiostoma solheimii B. Strzałka \& R. Jankowiak sp. nov. (Figure 8). MycoBank: MB830198

Etymology Named in honour of Prof. Halvor Solheim, in recognition of the leading role he has played in the study of diversity, ecology and taxonomy of the ophiostomatoid fungi, as well as for his leading role in developing the field of forest pathology in Europe.

Sexual state present Ascomata abundantly produced on media and on sterilized Quercus twigs, bases dark brown to black, globose to ovoid (299)329-457(-548) $\mu \mathrm{m}$ diam., ornamented with brown hyphal hairs of variable length (13.5-)20.7-65.9(108.6) $\mu \mathrm{m}$ long, 1.2-2.6 $\mu \mathrm{m}$ wide at the base (Fig. 8a, b). Necks black, straight or slightly curved, cylindrical, sometimes with bumps (1192-)1627-2218(-2569) $\mu \mathrm{m}$ long (Fig. 8c). Diameter of the necks (46.5)51.1-60.9(-67.1) $\mu \mathrm{m}$ at the base and (22.2)25.1-32.6(39) $\mu \mathrm{m}$ at the apex. Ostiolar hyphae not present; sometimes neck forms cup-shaped to funnellike opening at the apex (Fig. 8d, e). Asci not observed. Ascospores one-celled, orange-section shaped in side view (2.5-)2.6-3.1(-3.5) $\times(0.8-$ )1.1-1.4(-1.6) $\mu \mathrm{m}$, ellipsoidal in face view (2.3)2.7-3.2(-3.8) × (0.8-)1.1-1.6(-1.9) $\mu \mathrm{m}$, and circular in end view (mean $1.4 \mu \mathrm{m}$ ); sometimes with visible sheath situated towards the inside of the ascospore, to $1 \mu \mathrm{m}$ thick, accumulated in light brown-coloured mass at the tip of the neck (Fig. 8f).

Asexual states hyalorhinocladiella-like. Conidiophores mononematous, hyaline, terminal (4.7)11.7-45.1(-103.3) × (0.6-)0.9-1.8(-2.5) $\quad \mu \mathrm{m}$ (Fig. 8g, h). Conidia hyaline, smooth, one-celled, allantoid in side view $(2.9-) 3.7-5.1(-6.3) \times(0.8-$ )1.1-1.7(-2.2) $\mu \mathrm{m}$, ellipsoidal in face view (3.1)3.9-4.8(-5.3) × (0.9-)1.2-1.8(-2.1) $\mu \mathrm{m}$, and circular in end view (mean $1.5 \mu \mathrm{m}$ ) (Fig. 8i).
Culture characteristics Colonies with optimal growth at $25{ }^{\circ} \mathrm{C}$ on $2 \%$ MEA with radial growth rate $4.0( \pm 0.1) \mathrm{mm} / \mathrm{d}$, no growth occurred at $5{ }^{\circ} \mathrm{C}$. Colonies olive brown, margin smooth (Fig. 81). Hyphae olive yellow in colour (Kornerup and Wanscher 1978), smooth, submerged in the medium and aerial mycelium abundant, not constricted at the septa, 1.1-5.5 (mean $2.5 \pm 1$ ) $\mu \mathrm{m}$ diam. Chlamydosporelike cells terminal or intercalary present, in short chains, 3.1-9.9 (mean $5.9 \pm 1.6$ ) $\mu \mathrm{m}$ in diameter (Fig. 8j, k). Ascomata and asexual morph co-occur in culture.

Habitat: hardwood forest dominated by Quercus robur

Host tree: Quercus robur

Insect vectors: Anisandrus dispar

Distribution: Poland

Type material POLAND, Resko, in hardwood forest dominated by $Q$. robur, from A. dispar beetles infesting $Q$. robur, collector P. Wieczorek, 7 October 2016. Holotype dried specimen TUR 207548 (http:// mus.utu.fi/TFU.207548), ex-holotype living culture CBS 144881 = CMW 52050 .

Notes This species is most closely related to $O$. grandicarpum (Kowalski and Butin 1989). However, the DNA sequences of ITS, $\beta$ T, CAL and TEF1- $\alpha$ (Figs. 2, S4) clearly suggested that $O$. solheimii is distinct from $O$. grandicarpum. Morphologically, $O$. grandicarpum can be distinguished from this new species by distinctly larger perithecia and ascospores. In addition, $O$. grandicarpum has white colonies, while $O$. solheimii has olive brown colonies. Ophiostoma solheimii has been infrequently isolated from $Q$. robur L. in association with A. dispar (Jankowiak et al. 2019).

\section{Discussion}

In the present study, multigene phylogenies and morphological comparisons revealed four new species of Ophiostoma s. lato associated with five species of conifer- and hardwood-infesting bark beetles from the Czech Republic and Poland. These species were described herein as: Ophiostoma pityokteinis sp. nov., Ophiostoma rufum sp. nov., Ophiostoma solheimii sp. nov., and Ophiostoma taphrorychi sp. nov. 
$O$. rufum sp. nov. was assigned to the $O$. piceae species complex, as defined by Harrington et al. (2001) based on ITS sequence analysis of ten hardwood and conifer-inhabiting synnematous species. The monophyly of this group in Harrington's studies (2001) was not statistically supported. However, in subsequent studies, 'hardwood' species formed a separate lineage with substantial support, a lineage that was subsequently referred to as $O$. quercus species complex (Kamgan Nkuekam et al. 2011) or the $O$. ulmi species complex (De Beer and Wingfield 2013). The conifer-inhabiting species previously included in the $O$. piceae species complex (Harrington et al. 2001; Linnakoski et al. 2010) did not form a monophyletic lineage in recent reports based on ITS and LSU analyses (De Beer and Wingfield 2013; Yin et al. 2016). The monophyly of the $O$. piceae species complex was also not well supported in the present study. Nevertheless, based on individual proteincoding genes, as well as the phylogenetic analysis of the concatenated dataset these species formed a monophyletic lineage with substantial support. Yin et al. (2016) recommended the designation of a newly defined $O$. piceae species complex. They also noted that members of the $O$. piceae species complex have similar morphological characteristics such as unsheathed, allantoid ascospores, and pesotum-like synnemata and sporothrix-like asexual morphs. The monophyly of the $O$. piceae species complex based on three protein-coding gene regions, including $\beta \mathrm{T}, \mathrm{CAL}$ and TEF1- $\alpha$ sequence data was confirmed in the present study and $O$. rufum fits well into this species complex as a conifer-inhabiting species forming pesotum- and sporothrix-like asexual morphs.

$O$. rufum is highly similar to O. breviusculum, which was originally described from Ips subelongatus and Dryocoetes baikalicus infesting Japanese larch (Larix kaempferi) in Japan (Chung et al. 2006). The colony morphology on MEA is the main morphological difference between $O$. rufum and $O$. breviusculum . In addition, $O$. rufum produces shorter synnemata compared to $O$. breviusculum, and has unique crystalline structures in the upper part of the stipe. Ophiostoma breviusculum is considered heterothallic (Chung et al. 2006). Although we were not able to observe the sexual state, one would infer that $O$. rufum is also heterothallic. Ophiostoma rufum and $O$. breviusculum are also quite similar based on their host range and beetle vectors. Both species appear to be associated with Larix species (O. rufum with $L$. decidua, while $O$. breviusculum with $L$. kaempferi), and Ips species (O. rufum with I. cembrae, while $O$. breviusculum with $I$. subelongatus). However, the DNA sequences of $\beta$ T and TEF1- $\alpha$ obtained in this study clearly suggested that $O$. rufum is distinct from O. breviusculum.

The present study shows that $O$. pityokteinis sp. nov. has a unique ITS sequence. It forms a lineage within Ophiostoma s. stricto, grouping close to the O. piceae species complex and the $O$. distortum lineage. This new species is characterized by cup- or club-like synnemata, and the lack of a sporothrix-like anamorph. Sexual states were not observed for this species in crosses done between different isolates, suggesting that this species could be heterothallic. O. pityokteinis also has unique ecological characteristics; this fungus appears to be commonly associated with bark beetles infesting $A$. alba. In our previous study (Jankowiak et al. 2017a), $O$. pityokteinis was often found in association with Pityokteines species infesting A. alba in Poland (named as $O$. sp. 2), indicating that it might be a consistent fungal associate of this bark beetle species.

$O$. taphrorychi sp. nov. together with $O$. distortum are morphologically different from the other species in the $O$. piceae species complex and $O$. pityokteinis, and based on molecular data grouped in a distinct lineage within Ophiostoma s. stricto. In contrast to the members of the $O$. piceae species complex, O. taphrorychi and $O$. distortum do not produce pesotum-like synnemata, rather only sporothrix- or hyalorhinocladiella-like asexual morphs. Examination of additional isolates is needed to resolve the status of this apparently new clade or species complex.

$O$. taphrorychi is morphologically similar to $O$. distortum sensu Yin et al. (2016). A recent study has revealed that $O$. arduennense and $O$. torulosum are synonyms of $O$. distortum (Yin et al. 2016). However, there are some morphological and ecological differences, mainly between the asexual states. No asexual morph is known for O. arduennense (Carlier et al. 2006), while $O$. torulosum and $O$. distortum produce sporothrix-like morphs that differ in their conidial size and shape (Butin and Zimmermann 1972; Davidson 1971). Ecologically, O. arduennense and O. torulosum have been found in association with ambrosia beetles infesting F. sylvatica (Butin and Zimmermann 1972; Carlier et al. 2006), while O. distortum was described from Pityokteines sparsus infesting various conifer 
trees and unknown ambrosia beetle species (Davidson 1971). Morphologically, O. taphrorychi should be compared to $O$. torulosum, and to a lesser degree with O. arduennense. Ophiostoma torulosum can be distinguished from $O$. taphrorychi by forming ascomata in concentric rings, larger ascospores, and shorter ostiolar hyphae. In addition, $O$. torulosum produces a sporothrix-like asexual state; while $O$. taphrorychi has a hyalorhinocladiella-like morph producing larger primary or secondary conidia. Ophiostoma taphrorychi (previously referred as Ophiostoma sp. 8) appears to be closely associated with $T$. bicolor on F. sylvatica (Jankowiak et al. 2019). This species resides together with $O$. distortum in a discrete, wellsupported lineage in Ophiostoma s. stricto.

In the present study, $O$. solheimii sp. nov. together with $O$. grandicarpum and $O$. microsporum resided in a well-supported phylogenetic group referred to as lineage A by De Beer et al. (2016) supporting the view that this lineage probably represents a distinct genus in the Ophiostomatales (De Beer and Wingfield 2013; De Beer et al. 2016). Species in this lineage have small, orange-section shaped ascospores without noticeable sheath, and ascomata with very long necks without ostiolar hyphae (sometimes necks form cup-shaped to funnel-like openings at the apex). In addition, these fungi have hyalorhinocladiella-like asexual morphs (Davidson 1942; Kowalski and Butin 1989).

$O$. solheimii is morphologically most similar to $O$. grandicarpum (Kowalski and Butin 1989). These two fungi have homothallic mating systems and perithecia with long necks, however $O$. grandicarpum forms substantially larger ascomatal bases (up to $950 \mu \mathrm{m}$ in diam) and longer perithecial necks (up to $10000 \mu \mathrm{m}$ ) compared to $O$. solheimii. In addition, $O$. solheimii has smaller ascospores and cup-shaped to funnel-like openings at the apex of the perithecial necks. Both species produce hyalorhinocladiella-like asexual morphs. However, O. solheimii has smaller conidia than $O$. grandicarpum. In addition, $O$. solheimii can also be distinguished from $O$. grandicarpum by colony characteristics. The new species has olive brown colonies, while $O$. grandicarpum forms white to cream coloured colonies. Both species inhabit similar ecological niches. $O$. grandicarpum is known to occur mainly on $Q$. robur in Poland, the Czech Republic, Germany and Russia (Kehr and Wulf 1993; Kowalski and Butin 1989; Kowalski 1991; Novotný and Šrůtka 2004; Selochnik et al. 2015). The fungus was only rarely isolated from A. dispar and Scolytus intricatus on $Q$. robur in our previous study (Jankowiak et al. 2019). O. solheimii (previously referred as Ophiostoma sp. 9) so far has been found only in association with A. dispar on $Q$. robur (Jankowiak et al. 2019).

Recent surveys of conifer and hardwood-infesting bark beetles conducted in Czech Republic and Poland revealed many potentially new fungal species and new beetle-fungus associations (Jankowiak et al. 2017a, 2019). These findings clearly show that the Ophiostomatales associated with bark and wooddwelling beetles in Central Europe are very diverse and still poorly understood. In this study, we described four new taxa, which support the view that the diversity of these fungi is likely much higher than currently appreciated. Due to the economic impact of the Ophiostomatales it is important to formally describe species of Ophiostomatales that still remain undescribed. This will allow for a better understanding of the taxonomic status and diversity of these economically and ecologically important fungi.

Acknowledgements The authors gratefully acknowledge financial support from the National Science Centre in Poland (Contract No. UMO-2014/15/NZ9/00560). We thank the editor and three anonymous reviewers for their valuable comments.

Author's contribution RJ designed the study, performed the phenotypic and molecular characterization, wrote the original draft; PB performed the phenotypic and molecular characterization; $\mathrm{BS}$ and $\mathrm{AB}$ performed the phenotypic characterization; RL deposited fungal cultures, edited the original draft; $\mathrm{GH}$ helped with the analysis of molecular and taxonomic data, edited the original draft.

Funding This study was funded by the National Science Centre, Poland (Contract No. UMO-2014/15/B/NZ9/00560).

\section{Compliance with ethical standards}

Conflict of interest The authors declare that they have no conflict of interest.

Ethical approval All applicable international, national, and/ or institutional guidelines for the care and use of animals were followed.

Open Access This article is distributed under the terms of the Creative Commons Attribution 4.0 International License (http:// creativecommons.org/licenses/by/4.0/), which permits unrestricted use, distribution, and reproduction in any medium, provided you give appropriate credit to the original author(s) and the source, provide a link to the Creative Commons license, and indicate if changes were made. 


\section{References}

Aas T, Solheim H, Jankowiak R, Bilański P, Hausner G (2018) Four new Ophiostoma species associated with hardwoodinfesting bark beetles in Norway and Poland. Fungal Biol 122:1142-1158

Altschul SF, Gish W, Miller W, Myers EW, Lipman DJ (1990) Basic local alignment search tool. J Mol Biol 215:403-410

Butin H, Zimmermann G (1972) Zwei neue holzverfärbende Ceratocystis-Arten in Buchenholz (Fagus sylvatica L.). J Phytopathol 74:281-287

Carbone I, Kohn LM (1999) A method for designing primer sets for speciation studies filamentous ascomycetes. Mycologia 91:553-556

Carlier FX, Decock C, Jacobs K, Maraite H (2006) Ophiostoma arduennense sp. nov. (Ophiostomatales, Ascomycota) from Fagus sylvatica in southern Belgium. Mycol Res 110:801-810

Chang R, Duong TA, Taerum SJ, Wingfield MJ, Zhou XD, Yin M, De Beer ZW (2019) Ophiostomatoid fungi associated with the spruce bark beetle Ips typographus, including 11 new species from China. Persoonia 42:50-74

Chung W-H, Kim J-J, Yamaoka J, Uzunovic A, Masuya A, Breuil C (2006) Ophiostoma breviusculum sp. nov. (Ophiostomatales, Ascomycota) is a new species in the Ophiostoma piceae complex associated with bark beetles infesting larch in Japan. Mycologia 98:801-814

Darriba D, Taboada GL, Doallo R, Posada D (2012) jModelTest 2: more models, new heuristics and parallel computing. Nat Methods 9:772

Davidson RW (1942) Some additional species of Ceratostomella in the United States. Mycologia 34:650-662

Davidson RW (1971) New species of Ceratocystis. Mycologia 63:5-15

De Beer ZW, Wingfield MJ (2013) Emerging lineages in the Ophiostomatales. In: Seifert KA, De Beer ZW, Wingfield MJ (eds) The ophiostomatoid fungi: expanding frontiers, CBS biodiversity series 12 . CBS Press, Utrecht, pp 21-46

De Beer ZW, Duong TA, Wingfield MJ (2016) The divorce of Sporothrix and Ophiostoma: solution to a problematic relationship. Stud Mycol 83:165-191

Duong TA, De Beer ZW, Wingfield BD, Wingfield MJ (2012) Phylogeny and taxonomy of species in the Grosmannia serpens complex. Mycologia 104:715-732

Gardes M, Bruns TD (1993) ITS primers with enhanced specificity for Basidiomycetes - application to the identification of mycorrhiza and rusts. Mol Ecol 2:113-118

Glass NL, Donaldson GC (1995) Development of primer sets designed for use with the PCR to amplify conserved genes from filamentous ascomycetes. App Environ Microb 61:1323-1330

Grobbelaar J, De Beer ZW, Bloomer P, Wingfield MJ, Wingfield BD (2010) Ophiostoma tsotsi sp. nov., a woundinfesting fungus of hardwood trees in Africa. Mycopathologia 169:413-423

Guindon S, Gascuel O (2003) A simple, fast and accurate method to estimate large phylogenies by maximum-likelihood. Syst Biol 52:696-704

Guindon S, Dufayard JF, Lefort V, Anisimova M, Hordijk W, Gascuel O (2010) New algorithms and methods to estimate maximum-likelihood phylogenies: assessing the performance of PhyML 3.0. Syst Biol 59:307-321

Hall TA (1999) BioEdit: a user-friendly biological sequence alignment editor and analysis program for Windows 95/98/ NT. Nucleic Acids Symp Ser 41:95-98

Harrington T (1993) Diseases of conifers caused by species of Ophiostoma and Leptographium. In: Wingfield MJ, Seifert KA, Webber JF (eds) Ceratocystis and Ophiostoma: taxonomy, ecology and pathogenicity. American Phytopathological Society Press, St. Paul, pp 161-172

Harrington TC, McNew D, Steimel J, Hofstra D, Farrel R (2001) Phylogeny and taxonomy of the Ophiostoma piceae complex and the Dutch elm disease fungi. Mycologia 93:111-136

Jankowiak R (2005) Fungi associated with Ips typographus on Picea abies in Southern Poland and their succession into the phloem and sapwood of beetle-infested trees and logs. Forest Pathol 35:37-55

Jankowiak R (2006) Fungi associated with Tomicus piniperda in Poland and assessment of their virulence using Scots pine seedlings. Ann For Sci 63:801-808

Jankowiak R (2008) Fungi associated with Tomicus minor on Pinus sylvetris in Poland and their succession into the sapwood of beetle-infested windblown trees. Can J For Res 38:2579-2588

Jankowiak R, Bilański P (2013) Ophiostomatoid fungi associated with root-feeding bark beetles in Poland. Forest Pathol 43:422-428

Jankowiak R, Strzałka B, Bilański P, Kacprzyk M, Lukášová K, Linnakoski R, Misztela M, Rossa R (2017a) Diversity of Ophiostomatales species associated with conifer-infesting beetles in the Western Carpathians. Eur J For Res 136:939-956

Jankowiak R, Strzałka B, Bilański P, Linnakoski R, Aas T, Solheim H, Groszek M, de Beer ZW (2017b) Two new Leptographium spp. reveal an emerging complex of hardwood-infecting species in the Ophiostomatales. A van Leeuw J Microb 110:1537-1553

Jankowiak R, Ostafińska A, Aas T, Bilański P, Linnakoski R, Hausner G (2018) Three new Leptographium spp. (Ophiostomatales) infecting hardwood trees in Norway and Poland. A van Leeuw J Microb 111:2323-2347

Jankowiak R, Strzałka B, Bilański P, Kacprzyk M, Wieczorek P (2019) Ophiostomatoid fungi associated with hardwoodinfesting bark and ambrosia beetles in Poland: taxonomic diversity and vector specificity. Fungal Ecol 39:152-167

Kamgan Nkuekam G, De Beer ZW, Wingfield MJ, Roux J (2011) A diverse assemblage of Ophiostoma species, including two new taxa on eucalypt trees in South Africa. Mycol Prog 11:515-533

Katoh K, Standley DM (2013) MAFFT multiple sequence alignment software version 7 , improvements in performance and usability. Mol Biol Evol 30:772-780

Kehr RD, Wulf A (1993) Fungi associated with above-ground portions of declining oaks (Quercus robur) in Germany. Eur J For Pathol 23:18-27

Kirisits T (2001) Studies on the association of ophiostomatoid fungi with bark beetles in Austria with special emphasis on Ips typographus and Ips cembrae and their associated fungi Ceratocystis polonica and Ceratocystis laricicola. Dissertation, Universität für Bodenkultur (BOKU) Wien 
Kirschner R (2001) Diversity of filamentous fungi in bark beetle galleries in central Europe. In: Misra JK, Horn BW (eds) Trichomycetes and other fungal groups. Robert W. Lichtwardt Commemoration Volume. Science Publishers, Inc., Enfield, Plymouth, pp 175-196

Kornerup A, Wanscher JH (1978) Methuen handbook of colour, 3rd edn. Eyre Methuen, London

Kotýnková-Sychrová E (1966) Mykoflóra chodeb kůrovců v Československu. Česká Mycol 20:45-53 (in Czech with English summary)

Kowalski T (1991) Oak decline: I. Fungi associated with various disease symptoms on overground portions of Middle-aged and old oak (Quercus robur L.). Eur J Forest Pathol 21:136-151

Kowalski T, Butin H (1989) Taxonomie bekannter und neuer Ceratocystis-Arten an Eiche (Quercus robur L.). Phytophathol Z 124:236-248

Linnakoski R, De Beer ZW, Ahtiainen J, Sidorov E, Niemelä P, Pappinen A, Wingfield MJ (2010) Ophiostoma spp. associated with pine- and spruce-infesting bark beetles in Finland and Russia. Persoonia 25:72-93

Linnakoski R, Jankowiak R, Villari C, Kirisits T, Solheim H, De Beer ZW, Wingfield MJ (2016) The Ophiostoma clavatum species complex: a newly defined group in the Ophiostomatales including three novel taxa. Antonie van Leeuwenhoek J Microb 109:987-1018

Loo JA (2009) Ecological impacts of non-indigenous invasive fungi as forest pathogens. Biol Invasions 11:81-96

Malloch D, Blackwell M (1993) Dispersal biology of the ophiostomatoid fungi. In: Wingfield MJ, Seifert KA, Webber JF (eds) Ceratocystis and Ophiostoma: taxonomy, ecology, and pathogenicity. American Phytopathological Society Press, St Paul, pp 195-206

Novotný D, Šrůtka P (2004) Ophiostoma stenoceras and O. grandicarpum (Ophiostomatales) first records in the Czech Republic. Czech Mycol 56:19-32

O’Donnell K, Cigelnik E (1997) Two divergent intragenomic rDNA ITS2 types within a monophyletic lineage of the fungus Fusarium are nonorthologous. Mol Biol Evol 7:103-116

O’Donnell K, Kistler HC, Cigelnik E, Ploetz RC (1998) Multiple evolutionary origins of the fungus causing Panama disease of banana: concordant evidence from nuclear and mitochondrial gene genealogies. Proc Natl Acad Sci USA 95:2044-2049
Rambaut A, Drummond AJ (2007) Tracer v1.4. http://beast.bio. ed.ac.uk/Tracer. Accessed 8 Mar 2019

Robert V, Vu D, Amor AB et al (2013) MycoBank gearing up for new horizons. IMA Fungus 4:371-379

Ronquist F, Huelsenbeck JP (2003) MrBayes 3: Bayesian phylogenetic inference under mixed models. Bioinformatics 19:1572-1574

Selochnik NN, Pashenova NV, Sidorov E, Wingfield MJ, Linnakoski R (2015) Ophiostomatoid fungi and their roles in Quercus robur die-back in Tellermann forest, Russia. Silva Fenn 49(5):16. https://doi.org/10.14214/sf.1328

Siemaszko W (1939) Zespoły grzybów towarzyszących kornikom polskim. Planta Pol 7:1-54 (in Polish with English summary)

Swofford DL (2003) PAUP*. Phylogenetic analysis using parsimony (* and othermethods). Version 4. Sinauer Associates, Sunderland

Sydow H, Sydow P (1919) Mykologische Mitteilungen. Ann Mycol 17:33-47

Tamura K, Stecher G, Peterson D, Filipski A, Kumar S (2013) MEGA6: molecular evolutionary genetics analysis version 6.0. Mol Biol Evol 30:2725-2729

White T, Bruns T, Lee S, Taylor J (1990) Amplification and direct sequencing of fungal ribosomal RNA genes for phylogenetics. In: Innis MA, Gelfand DH, Snisky JJ, White TJ (eds) PCR protocols: a guide to methods and applications. Academic Press, New York, pp 315-322

Wingfield MJ, Brockerhoff EG, Wingfield BD, Slippers B (2015) Planted forest health: the need for a global strategy. Science 349(6250):832-836

Wingfield MJ, Barnes I, De Beer ZW, Roux J, Wingfield BD, Taerum SJ (2017) Novel associations between ophiostomatoid fungi, insects and tree hosts: current status-future prospects. Biol Invasions 19:3215-3228

Yin M, Wingfield MJ, Zhou X, De Beer ZW (2016) Multigene phylogenies and morphological characterization of five new Ophiostoma spp. associated with spruce-infesting bark beetles in China. Fungal Biol 120:454-470

Publisher's Note Springer Nature remains neutral with regard to jurisdictional claims in published maps and institutional affiliations. 